University of Louisville

ThinkIR: The University of Louisville's Institutional Repository

Electronic Theses and Dissertations

8-2011

\title{
Constructing British identity : Tobias Smollett and his Travels through France and Italy
}

Michael Anthony Skaggs 1987-

University of Louisville

Follow this and additional works at: https://ir.library.louisville.edu/etd

\section{Recommended Citation}

Skaggs, Michael Anthony 1987-, "Constructing British identity : Tobias Smollett and his Travels through France and Italy" (2011). Electronic Theses and Dissertations. Paper 1336.

https://doi.org/10.18297/etd/1336

This Master's Thesis is brought to you for free and open access by ThinkIR: The University of Louisville's Institutional Repository. It has been accepted for inclusion in Electronic Theses and Dissertations by an authorized administrator of ThinkIR: The University of Louisville's Institutional Repository. This title appears here courtesy of the author, who has retained all other copyrights. For more information, please contact thinkir@louisville.edu. 


\title{
CONSTRUCTING BRITISH IDENTITY: TOBIAS SMOLLETT AND HIS \\ TRAVELS THROUGH FRANCE AND ITALY
}

\author{
By \\ Michael Anthony Skaggs \\ B.A., Indiana University, 2005

\begin{abstract}
A Thesis
Submitted to the Faculty of the

College of Arts and Sciences of the University of Louisville in Partial Fulfillment of the Requirements

for the Degree of
\end{abstract}

Master of Arts

Department of History

University of Louisville

Louisville, KY

August 2011 
Copyright 2011 by Michael Anthony Skaggs

All rights reserved 


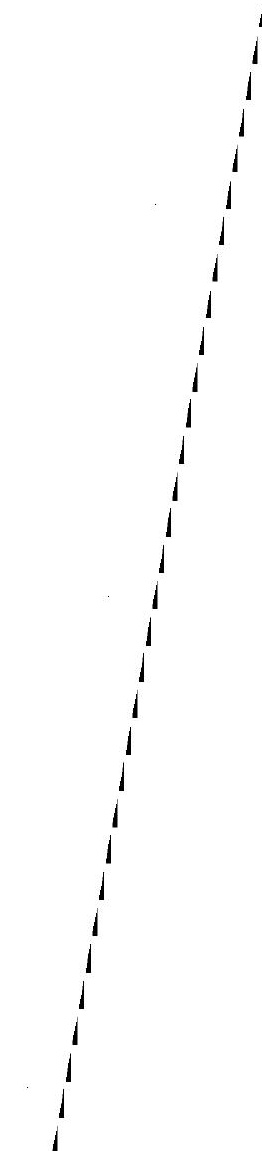


CONSTRUCTING BRITISH IDENTITY: TOBIAS SMOLLETT AND HIS

TRAVELS THROUGH FRANCE AND ITALY

By

Michael Anthony Skaggs

B.A., Indiana University, 2005

A Thesis Approved on

June 13, 2011

By the following Thesis Committee:

John McLeod, Ph.D. -Thesis Director

Daniel Krebs, Ph.D.

Glynis Ridley, Ph.D. 


\section{DEDICATION}

This thesis is dedicated to the people who contributed more than I could ask and made enormous sacrifices to get me where I am today: my grandparents, Margaret Eddings and Earl Trimble, and my parents, Brenda and Michael L. Skaggs.

You made this possible. 


\section{ACKNOWLEDGEMENTS}

I would like to thank my advisor, Dr. John McLeod, for allowing me the freedom to pursue my interest in the British in the ways I wanted to and providing direction when I had no idea which way to go. He has provided invaluable advice on many occasions and introduced me to the world of history - which, as it turns out, is rather different from what I thought it was when I began this program. Thanks are also due to the other members of the committee: to Dr. Daniel Krebs, for an introduction to Atlantic history during my first semester at the University of Louisville, and to Dr. Glynis Ridley, for her enthusiastic agreement to serve as a reader. The service of all three committee members is deeply appreciated. I also owe thanks to Lee Keeling, Program Assistant to the History Department, who provided invaluable help in submitting this work.

I would be remiss to not acknowledge the men and women who have fueled my educational career. It is no exaggeration to say that this project would never have come into being without the support of many kind benefactors from my earliest years of elementary school to the donors who funded the undergraduate and graduate scholarships that made my education possible.

Finally, this thesis would not have been possible without the encouragement, love, and unswerving faith of my fiancée, Caroline. There were many occasions on which I was certain this project would not be complete. It is thanks to her that I pushed myself to dig deeper, write more, and think outside the box. Throughout my academic career she has reminded me day after day: "Yes, you can." 


\section{ABSTRACT \\ CONSTRUCTING BRITISH IDENTITY: TOBIAS SMOLLETT \\ AND HIS \\ TRAVELS THROUGH FRANCE AND ITALY}

\section{Michael Anthony Skaggs}

June 13, 2011

This thesis examines Tobias Smollett's Travels through France and Italy as a product of the dynamics influencing British identity in the eighteenth century. Specifically, it compares Smollett's Travels with recent trends in the historiography of British identity and Atlantic history and defines Smollett's place in those scholarly debates. By using Tobias Smollett as an individual and Travels as reflections of Smollett's own conception of British identity, this thesis highlights some of the shortcomings of extant historiography on British identity and Atlantic history. It particularly engages issues of authority, power, religious belief, and the self/other dichotomy as they contribute to both collective and individual senses of national identity. Finally, the author intends for this thesis to raise questions about certain historiographical assumptions and analyzes their utility in specific contexts. 


\section{TABLE OF CONTENTS}

PAGE

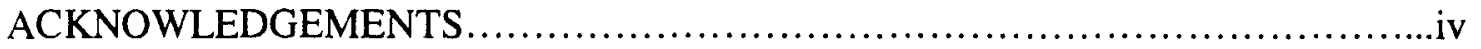

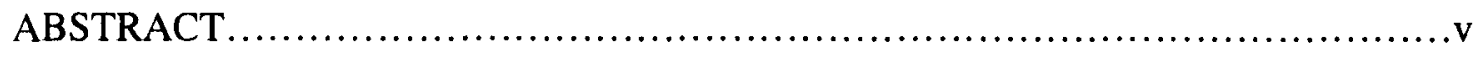

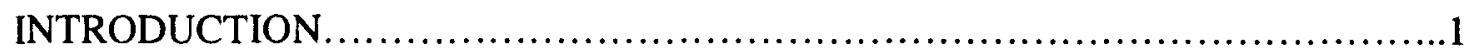

CHAPTER ONE: Smollett, Britishness, and the Atlantic World.....................11

CHAPTER TWO: One of the Atlantics: A British Perspective.........................58

CHAPTER THREE: Tobias Smollett's Travels through France and Italy..............77

CONCLUSION........................................................... 100

REFERENCES........................................................... 104

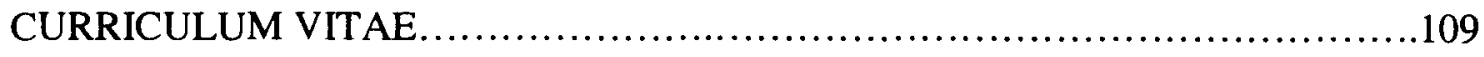




\section{INTRODUCTION}

Between 1700 and 1799, who were the British?

"The British" as a historical subject are often taken for granted. Books, articles, and essays on "the British" number in the tens of thousands, yet of those works one would be hard pressed to sort through them all for the authors that specifically define who "the British" were, aside from descriptions of the political processes uniting England and Wales to Scotland in 1707. And even among the subset that offers a definition for the British, a large number would likely define the people along externally imposed lines, declaring the British to be "inhabitants of the British Isles," or "the members of the United Kingdom from 1707 on," "the composite body made up of English, Welsh, and Scottish peoples in the eighteenth century," or something similar.

But what would the British themselves say, were the historian able go back in time and ask them? How would the British define themselves as a people, and what components of national identity could they highlight to show their commonalities? Importantly, who could the historian ask for such an answer? This thesis seeks to question Tobias Smollett, Scottish doctor, poet, playwright, and author for answers to these questions. Specifically, it will analyze Smollett's Travels through France and Italy as documentary evidence of constructing British identity in the eighteenth century, with the assistance of scholars who are currently engaged in establishing a comprehensive image of the British as inhabitants of the island kingdom. 
In recent years, a radically different school of thought has begun to analyze the British within a much broader context. Historians have become aware that the similarities, differences, moments of competition, and historical legacies of multiple entities - including the empires of the British, French, Spanish, Dutch, and Portuguese formed a world to their west that would enable historians to view all of them in a new light. That world took the apparently obvious name of "Atlantic world." The obvious nature of this appellation is geographic only: clearly, the empires in question all shared (or in many cases fought over) the same body of water. Or did they? Was the British Atlantic the same as the Portuguese Atlantic? Did the Spanish utilize the vast waters into which the Iberian Peninsula projects for the same reasons as the French? And was the meaning of those waves the same for the British as it was for the Dutch?

Subsequent historiography has revealed that the answer to the above questions is no. And so one understands that the Atlantic Ocean, while unitary and relatively straightforward in its own right, it is incomprehensible as such when approaching it from the perspective of the various peoples who utilized that body of water for different purposes. Rather, the Atlantic becomes a platform upon which very different histories played out. In this manner, the Atlantic Ocean of the British is not the Atlantic Ocean of the Spanish, any more than the government of the British is comparable to the government of the Spanish: these things do not equal each other, and the way in which historians understand each depends exclusively upon the unique histories of both.

Such a conceptual structuring of history introduces something of a problem to approaching the British as a nation, understood here to be a group of people defined internally by a set of self-imposed standards. In many ways there is significant overlap 
between the history of Britain as it unfolded in the Atlantic Ocean and Atlantic history itself; this is not to say, however, that such an overlap allows the historian to kill two birds with one stone. British history from the standpoint of a northwestern European people with imperial connections stretching around the world is radically different from British history seen through the lens of Atlantic history; similarly, there is a vast difference between thinking of British people as inhabitants of an island country and British people as inhabitants of an enormous oceanic region. It seems necessary, therefore, to explore the points of intersection and divergence between these two modes of thought. The practice of viewing any given group of people through a variety of lenses is certainly nothing new, but how do these two views differ in reference to the British?

This thesis seeks to answer that question by analyzing the issues of British selfidentification woven throughout Tobias Smollett's Travels through France and Italy. The current historiography on Smollett has not provided a satisfactory answer to the questions of Smollett's own interpretation of Britishness and the utility of his Travels as a sourcebook of British identity; this thesis is an attempt to fulfill that need. It will also compare several significant examples of the historiographies of British identity and the Atlantic world for the purposes of highlighting the connections and divergences of the two. The Atlantic perspective in the eighteenth century is an important consideration, and this thesis aims to address Atlanticism's strengths and weaknesses in an analysis of its applicability to British identity. Finally, an exposition of Smollett's Travels will provide an example of the relationship between those two viewpoints in the context of eighteenthcentury British identity and its construction by Tobias Smollett. 
Tobias Smollett was a fascinating man in his own time, and those with whom he interacted and maintained correspondence were well aware of his rather colorful character - for better or worse, few could accuse Smollett of being boring. From a distance of two and a half centuries, however, Smollett raises questions crucial to understanding the dynamics of constructing a national identity in the eighteenth century. In what ways did Smollett - a Scot - fit into the English capital? In what ways did Smollett - a Briton - fit into the French and Italian places he visited? More directly, just how British was Tobias George Smollett, and how can historians arrive at an answer?

\section{$* * *$ \\ Tobias Smollett: Scottish Transplant into the British World ${ }^{3}$}

Tobias George Smollett was born on or about March 16, 1721 into a fairly wellestablished Dumbartonshire family. ${ }^{4}$ Although Smollett's father did not leave the family with a fortune after his death, Tobias's childhood was decent. ${ }^{5}$ While attending the University of Glasgow he felt drawn to a career in medicine. ${ }^{6}$ Subject to the practical demands of finding employment, Smollett set out for London in an effort to establish himself as a physician. As he enjoyed English literature and dabbled in writing himself, the literary merits of the British capital were no small benefit to this southward journey ${ }^{7}$ Although he arrived in London with medical and literary expectations for his time in the

\footnotetext{
${ }^{3}$ A number of authors was consulted in constructing this brief introduction to Smollett; however, the most significant biographer of Smollett to date is Lewis M. Knapp, who published his biography in 1949.

${ }^{4}$ Oliphant Smeaton, Tobias Smollett (New York: Charles Scribner's Sons, 1897), 12 and Lewis M. Knapp, Tobias Smollett: Doctor of Men and Letters (Princeton: Princeton University Press, 1949), 6. Smeaton directly provides this date, although he is the only one of Smollett's biographers to do so. P.-G. Boucé takes issue with Smeaton's biography, but it is useful here for a general outline of Smollett's life. See P.-G. Boucé, "Eighteenth and Nineteenth-Century Biographies of Smollett" in Tobias Smollett: Bicentennial Essays Presented to Lewis M. Knapp, ed. G. S. Rousseau and P.-G. Boucé (New York: Oxford University Press, 1971).

${ }^{5}$ Knapp, Doctor of Men and Letters, 7 and Smeaton, Tobias Smollett, 16.

${ }^{6}$ Smeaton, Tobias Smollett, 16.

${ }^{7}$ Smeaton, ibid, 33 and Knapp, Doctor of Men and Letters, 18.
} 
capital, he eventually looked to military service as a possible source of income. It was thus that Smollett volunteered for the British Navy and received a commission as a second surgeon's mate on the Chichester in 1740 before setting out for the disastrous Cartagena expedition. ${ }^{8}$ After his service as a surgeon's mate during the ill-fated action at Cartagena, Smollett established his own practice as a physician in Jamaica in 1742; by 1744, he was back in London, where he primarily associated with fellow Scotsmen. ${ }^{9}$ In the meantime, however, Smollett had met, courted, and married Anne Lascelles. The exact date of marriage between the two is unknown, although Smollett's biographers have speculated dates from 1743 to 1747 . In any case, there is evidence to suggest that some type of ceremony was performed in Jamaica in 1743 with an additional service to formalize the Jamaican ceremony at a later date. ${ }^{10}$

Upon arriving back in England, Smollett continued his medical practice; Lewis Knapp convincingly suggests that Smollett's occupation of the surgery left behind by John Douglas (an expenditure in itself probably possible only due to the new Mrs. Smollett's personal wealth) hints at long-term medical practice aspirations. "Smollett's eventual record of writing and publishing are the fruits of a major career change on the doctor's part, although his biographers are not in agreement as to why he decided to throw himself into the literary world. Kahrl maintains that "only when time passed and the lucrative practice did not materialize did he gradually resort to writing for a living."12 Knapp presents earlier arguments that Smollett's abandonment of medicine as a career

\footnotetext{
${ }^{8}$ George M. Kahrl, Tobias Smollett: Traveler-Novelist (Chicago: University of Chicago Press, 1948), 3. Kahrl writes "Neither Smollett's reasons for joining the expedition nor the circumstances of his assignment to the Chichester are known"; Knapp also offers no real explanation, but does mention that Smollett felt "proud dignity" in his service. See Knapp, Doctor of Men and Letters, 32.

${ }^{9}$ Smeaton, Tobias Smollett, 43 and Kahrl, Traveler-Novelist, 71.

${ }^{10}$ Smeaton, Tobias Smollett, 43 and Knapp, Doctor of Men and Letters, 43.

${ }^{11} \mathrm{Knapp}$, ibid, 46 and 48.

${ }^{12}$ Kahrl, Traveler-Novelist, 12.
} 
was due to the man's rather irritable personality and unwillingness to suffer the eccentricities of patients; more convincing is Knapp's own argument that "there is...evidence that a medical degree from Aberdeen [from where Smollett received his M.D. in 1750] or from St. Andrew's was vigorously depreciated in Smollett's time." Regardless of the reasons for Smollett's career switch, from the 1740's until the end of his life Tobias Smollett became known for his work as an author and both enjoyed fame and endured scorn for those literary aspirations.

Smollett's output ranged from hackwork, to history, to novels of high critical reception and public response. ${ }^{14}$ Some of his most important works include The Adventures of Roderick Random, The Adventures of Peregrine Pickle, a translation of Don Quixote, and the editorship of The Critical Review; it is his publication of Travels through France and Italy with which this thesis is most concerned and which will be discussed below. ${ }^{15}$ Along with these works are some of Smollett's less immediately recognizable pieces, including The Regicide, The Reprisal and "The Tears of Scotland." Despite what has become an impressive bibliography Smollett did not always enjoy great personal or financial success, and upon closer inspection the course of his life appears to be a series of questionable decisions and rather petty squabbles that brought far more discomfort than they were worth.

Smollett did not enjoy financial wealth almost from the beginning of his life; when he decided to move to London, he arrived in the capital with plenty of moral

\footnotetext{
${ }^{13}$ Knapp, Tobias Smollett. 144-145.

${ }^{14}$ Donald Greene points out that some commentators have included Smollett's Continuation of the Complete History of England in his catalog ofhackwork; however, Greene contends that "hackwork is not necessarily a guarantee of complete absence of merit." See Greene, "Smollett the Historian" in Bicentennial Essays Presented to Lewis M. Knapp, 28.

${ }^{15}$ Far beyond the scope of this thesis, Knapp's biography examines each of Smollett's works in great detail.
} 
support but little in the way of concrete resources. ${ }^{16} \mathrm{Kahrl}$ 's biography claims that Smollett's literary ambitions were fueled by financial failure in medical practice; Knapp points out that Smollett's hack work unfortunately generated little income. ${ }^{17}$ The vast amounts of time Smollett spent as a defendant in two lawsuits were not helpful to his financial stability, either. ${ }^{18}$

The more popular pieces of Smollett's work - Peregrine Pickle, Roderick Random, and so on - certainly provided ample income, but Smollett's social inclinations saw to it that this money did not last long. Knapp writes that

He drove himself [to produce a high volume of writing] thus, largely because, prior to the financial success of his History of England in 1758, he was frequently in debt. He lacked funds not because his income (which included what his wife received from the West Indies) was small, but because he was generous to the point of neglecting his family expenses. ${ }^{19}$

Smollett was apparently rich in kindness but not in financial wisdom.

Smollett's literary career also served as an outlet for another component of his personality often commented upon both during and after Smollett's life: the man's rather irritable personality, the product of what Knapp called "the fierce pride, resentment, and indignation which tormented Smollett all his life."20 Throughout his life, and especially during his most active years of literary output, Smollett was quick to dish out criticism sometimes rather harshly - but was incapable of receiving the same. Smollett easily took offense outside the realm of literary criticism, as well: one of the aforementioned lawsuits arose from Smollett's physical assault on two men, one of whom was attempting to

\footnotetext{
${ }^{16}$ Knapp, Doctor of Men and Letters, 27.

${ }^{17}$ Kahrl, Traveler-Novelist, 12 and Knapp, Doctor of Men and Letters, 151.

${ }^{18}$ At one point Smollett was tried for assault but acquitted (see Knapp, Doctor of Men and Letters 151153); later, he was convicted and imprisoned for libel against a naval officer (see Knapp, ibid, 213-214).

${ }^{19}$ Knapp, Doctor of Men and Letters, 181.

${ }^{20}$ Knapp, Doctor of Men and Letters, 10.
} 
renege on a loan extended to him by Smollett. ${ }^{21}$ Kahrl offers perhaps the best summary of Smollett's personality, expressed through his skills as a novelist: "Too often to the disadvantage of his novels, however, he was a satirist by temperament and not by knowledge or precept." 22

In April of 1763, disaster struck the Smollett household when the Smolletts' fifteen-year-old daughter Elizabeth died; Tobias and Anne were overwhelmed with grief. ${ }^{23}$ Despite the tragic nature of Elizabeth's death, the event proved to be the impetus for one of Smollett's most significant works. Smollett decided that he and his wife would set out on a journey across the Channel to the Continent in an attempt to put distance between themselves and the scene of their grief and recover their emotional health; in declining physical health after years of exhaustive work, Smollett also wanted to take in the airs of southern France and recuperate. ${ }^{24}$ It was on this journey that Smollett wrote his Travels through France and Italy, an account that assumed the form of letters to fictional recipients detailing Smollett's experiences in those countries. Smollett returned to Britain in 1765; while he felt that his time in France had done a great deal of work toward restoring his health, the effect was not permanent and he returned to Italy in 1768 . It was here that Smollett died in September 1771.

Despite the volume of Smollett's other literary output it is his Travels through France and Italy which this thesis seeks to explore. Travels is a work through which Smollett's apparent personality shows clearly: when Laurence Sterne published $A$

\footnotetext{
${ }^{21}$ Knapp, Doctor of Men and Letters, 151.

${ }^{22} \mathrm{Kahrl}$, Traveler-Novelist, 25.

${ }^{23}$ Knapp, Doctor of Men and Letters, 247.

${ }^{24}$ Knapp, ibid, 247.
} 
Sentimental Journey in 1768 , he made sure to include meeting a character modeled on Smollett. Upon meeting this character, Sterne writes

The learned Smelfungus travelled from Boulogne to Paris - from Paris to Rome - and so on - but he set out with the spleen and jaundice, and every object he pass'd by was discoloured or distorted - He wrote an account of them, but 'twas nothing but the account of his miserable feelings. ${ }^{25}$

True enough, Smollett's rather irritable side rears its head throughout Travels. The work is nonetheless a useful tool for understanding one man's self-conception as a Briton in the eighteenth century, and as such Travels can be used as a window onto the complex process of constructing the distinctly British identity just emerging in the mid-eighteenth century.

The essential structure of Travels is a series of letters written to fictional recipients during Smollett's time spent visiting various cities in France and Italy, including Boulougne, Nice, Montpelier, Florence, Turin, and Rome. While in these places Smollett offers commentary on such expected topics as travel conditions, the lodgings available to him and his party, meals taken, and leisurely activities. Smollett's letters also include detailed commentaries - usually scathing - on some treatment he has received at the hands of a host or event observed in the local setting. Crucial to the utility of taking Smollett as an example of eighteenth-century British identity is his magnification of individual occurrences onto a national scale. When encountering something new, strange, and (most often) objectionable, Smollett takes the opportunity to criticize both the thing observed and the nation at large: encountering a rude Frenchman

\footnotetext{
${ }^{25}$ Laurence Sterne, A Sentimental Journey through France and Italy by Mr. Yorick, ed. Gardner D. Stout, Jr. (Berkeley: University of California Press, 1967), 116. Originally published London, 1768.
} 
leads Smollett to conclude all Frenchmen are rude. ${ }^{26}$ By the same token, Smollett takes his own reaction to whatever distasteful display or concept to be indicative of a general British sensibility, speaking for the whole of Britain as he pronounces judgment upon the French and Italians.

In this way the rather limited experiences of Tobias Smollett are (by Smollett's own intention) illustrative of the tensions between the British and the French and the entire process of constructing a uniquely British identity. This thesis does not seek to commit the same mistake as Smollett and assume that an analysis of his Travels will yield a total understanding of all Britons; however, it does highlight Smollett's travel writing as a well-articulated example of the issues involved in creating a sense of "Britishness." The utility of Travels lies in the background of its author: Tobias Smollett was a Scotsman but also a subject of the British king; he held fond memories of Scotland but constantly referred to English superiority as though it were his own. Throughout Travels, Smollett speaks freely of Scotland, England, and Britain, conveying to the reader that he conceives of these three entities as intimately related. It is both a detriment and an advantage that Smollett does not explicitly address the vagaries of piecing together a British identity in the mid-eighteenth century: while the reader would appreciate insight directly from the man himself, his casual swapping of terminology is telling even as it slips by almost undetected.

\footnotetext{
${ }^{26}$ Let not the modern reader think Smollett only commented on the males of society on his travels: he commented on French women as well, noting that the only reasonable explanation for their receptivity of male vanity was feminine stupidity. See Tobias Smollett, Travels through France and Italy, ed. Frank Felsenstein (New York: Oxford University Press, 1979), Letter VII. Originally published London, 1766.
} 


\section{CHAPTER ONE: SMOLLETT, BRITISHNESS, AND THE ATLANTIC WORLD}

Before delving into the deeper questions surrounding Tobias Smollett's Travels through France and Italy, it is necessary to spend some time reviewing the extant historiography on questions of British identity raised by Smollett. This review is by no means intended to be a comprehensive bibliography of all works examining British identity in the eighteenth century; however, it will take a look at some of the work that is helpful when considering Smollett's construction of British identity. Specifically, it will briefly present the biography of Smollett and the ways in which the British saw other Europeans during the eighteenth century. It will additionally examine the state of Atlantic history and its integration with concepts of British identity.

\section{I}

\section{$\underline{\text { Tobias Smollett }}$}

Tobias Smollett does not enjoy the posthumous celebrity of some other Britons; as a result, biography on Smollett is not as substantial as that of others. This is not to suggest that nothing of value has been written on Smollett - quite the contrary - but he is not as well known as some other eighteenth century literary figures, especially in terms of modern historiography.

Oliphant Smeaton authored a biography of Smollett in 1897, contributing to the "Famous Scots Series" of national biography. Smeaton leaves the reader with some questions as to who exactly Smollett was. He initially writes that Smollett may have 
claimed political allegiance to the Whigs, but was in reality a Tory. ${ }^{1}$ Toward the end of his biography Smeaton contends "though a Tory in name, he was in reality more of a philosophical Whig, rather a champion of the rights of the people than a love and defender of aristocracies, oligarchies, and monopolies." ${ }^{2}$ Although this may seem to be a minor point, Smollett's political allegiance is an important facet of the man (especially within the context of rather intense eighteenth-century British politics). Significant to this thesis, however, is Smeaton's clear description of Smollett's self-conception as a British man:

To Smollett the soul of patriotism was summed up in sinking the name of Scot in the generic one of Briton, and in endeavoring to stamp out that pitiful provincialism that considered one's love of country to be best manifested in perpetuating quarrels whereon the mildew of centuries had settled. ${ }^{3}$

According to Smeaton, Smollett was a Briton - end of story. Whether he was entirely correct or not will be examined throughout this thesis.

As the series title suggests, Smeaton's treatment of Dr. Smollett is not completely objective; this may go some way toward explaining Smeaton's vagueness. In the opening pages of his biography Smeaton rushes to Smollett's defense by saying

The eagle eye of his genius perceived intuitively what other men generally attain only as the result of the ratiocinative process. Smollett has unjustly been characterised as bad-tempered, choleric, supercilious, and the like, simply because the key was lacking to his character. Far indeed from being any of these was he...[t]here is a prodigality visible, nay, an intellectual waste, indicative of an imaginative wealth almost unique since the days of Homer. ${ }^{4}$

\footnotetext{
' Oliphant Smeaton, Tobias Smollett (New York: Charles Scribner's Sons, 1897), 49. Some evidence for this claim comes from Smollett's authorship of the poem "Tears of Scotland," written in the wake of the Culloden massacre, and Whig criticism of Smollett as "a partisan and panegyrist of the House of Stuart, a Papist and a prostitute" after publication of his History. See Smeaton, Tobias Smollett, 50 and 98.

${ }^{2}$ Smeaton, Tobias Smollett, 139.

${ }^{3}$ Smeaton, Tobias Smollett, 143.

${ }^{4}$ Smeaton, Tobias Smollett, 10-11.
} 
Such high praise should raise an eyebrow or two as it appears out of place to the twentyfirst century reader. Whether it was deserved or not is irrelevant. Its presence indicates a lack of objectivity that significantly lessens Smeaton's value as a critical biographer of Tobias Smollett. $^{5}$

By the mid-twentieth century, scholars had considerably improved the state of Smollett's biography. In 1945 George M. Kahrl published his Tobias Smollett: TravelerNovelist. This biography serves as an important counter to Smeaton's adoration, which borders on saccharine-sweetness. In addition to providing the more pedestrian details of Smollett's life, Kahrl begins an analysis of Smollett's status as something of an outsider in England and thus allows the reader to examine much more significant questions about Smollett's importance as an eighteenth-century Briton. In this way, Kahrl is a crucial example of pursuing biography of Smollett in a more probing and theoretical manner.

Unfortunately, Kahrl spoils an opportunity to publish a more convincing thesis on how Smollett's Scottishness played into his sense of national identity. Kahrl makes clear references to "a hostile English London" in which Smollett worked, the influence on his writings applied by status as "an alien Scot," the "racial animosity of London [that] isolated Smollett and restricted his social life to the company of Scots," and Smollett's "constant effort to avoid antagonizing English readers." Strangely, Kahrl reverses these significant claims by writing "in the present state of Smollett's biography, it is difficult to estimate the effect of English antipathy upon his life and works. In his public utterances

\footnotetext{
${ }^{5}$ For a more detailed criticism of Smeaton, see P.-G. Boucé, "Eighteenth and Nineteenth Centuries of Smollett" in Tobias Smollett: Bicentennial Essays Presented to Lewis M. Knapp, ed. G. S. Rousseau and P.-G. Boucé (New York: Oxford University Press, 1971). Boucé also provides a much richer account of early biography of Smollett, which is beyond the scope of this short thesis.
} 
on the whole he maintained a passive attitude."6 Smollett's "public utterances" may provide little evidence for how much being Scottish in a predominantly English capital affected the man's writing, but Kahrl's exposition of Smollett's social life points directly to a very powerful influence on Smollett on the whole. One can hardly argue that such influence did not affect his writings, especially given Kahrl's mention that Smollett worked very hard to please a specifically English audience. In the larger scope of establishing British identity from the life of Tobias Smollett, Kahrl's equivocation becomes problematic and handicaps his usefulness to an understanding of Smollett.

Close on the heels of Kahrl's publication came Lewis Mansfield Knapp, arguably the twentieth century's most significant Smollett scholar who published what is still the standard biographical reference work. Knapp's biography examines Smollett from many directions, providing detailed timelines of Smollett's life; analyses of Smollett's personality and the forces at work in the creation of Smollett's medical and literary careers; and serviceable discussions of Smollett's poems, novels, plays, and other writings. Knapp's biography covers some of the critical components of Smollett's identity, including Smollett's religious views, his political opinions, and his selfconception as a Briton and a Scotsman.

One of the most significant components of Knapp's biography is introduced early on and reappears throughout the book. This is Knapp's definition of what Smollett is often remembered for: his attitude. Knapp notes "a central emotional pattern in Smollett's life - an irritating obsession of persecution, and the quick, instinctive reaction, so often repeated, of revenge, not only threatened but usually executed with the weapons of satire

\footnotetext{
${ }^{6}$ George M. Kahrl, Tobias Smollett: Traveler-Novelist (Chicago: University of Chicago Press, 1945), 61, 65,71 , and 70 , respectively.
} 
and even with a cudgel."7 Despite the fact that much of Smollett's literary career was built around satirizing or directly attacking a wide variety of people and institutions, the man was not a calm recipient of criticism. When a libretto Smollett had written was not welcomed to the opera with open arms, Smollett screeched that the man who had rejected it was "'an infatuated miscreant,' 'a compound of indolence, Worthlessness, and folly.",8

Knapp also provides a glimpse into Smollett's political and religious backgrounds, although his mentions usually point to more confusion and vagueness. He writes that the family from which Smollett came was "Whig...in politics, Presbyterian in religious persuasion." ${ }^{\text {'9 }}$ Later, Knapp notes that Smollett apparently moved away from this origin as "aristocratic features of Smollett appear in his growing political Toryism, and in his shift from the Presbyterianism of his youth to his association with the Church of England in Chelsea." Knapp later offers a possible explanation for this apparent change by noting that Smollett disliked Protestant fanatics and his writing may have even leaned toward Methodism. ${ }^{10}$ Perhaps the most confident assertion Knapp makes is that Smollett's "frequent attacks on enthusiasts and fanatics indicate that he recognized the great value of rational control over emotion."11

Knapp does approach some of the issues Smollett faced as a Scot in London and Smollett's social interactions as an alien in the capital; however, he does not commit the same vacillating mistake of Kahrl in terms of Smollett's Scottish connections. As far as Smollett's social circle went, Knapp writes that it "was made up almost entirely of

\footnotetext{
${ }^{7}$ Lewis Mansfield Knapp, Tobias Smollett: Doctor of Men and Letters (Princeton: Princeton University Press, 1949), 12. Knapp's reference to a cudgel comes from Smollett's assault trial, mentioned earlier.

${ }^{8}$ Knapp, Doctor of Men and Letters, 75.

${ }^{9}$ Knapp, Doctor of Men and Letters, 6.

${ }^{10} \mathrm{Knapp}$, Doctor of Men and Letters, 305, 307.

" Knapp, Doctor of Men and Letters, 304.
} 
Scotsmen," including the author of the later-famous "Rule Britannia" and some of the most important doctors and surgeons of the day." ${ }^{12}$ When Smollett moved his family out to Chelsea from London, his perspective on the English was not improved: he could not understand the ignorance of some Englishmen who were under the impression a sea lay between England and Scotland and that the current pope was but one of several "in service," as it were. ${ }^{13}$

The body of Smollett's biography does not, unfortunately, provide the necessary depth of conceptual exploration to truly understand some of the most significant forces of British identity in Smollett's day and their effect on British self-identification. For this reason it is necessary to turn to some of the more narrowly focused literature on Britons and their attitudes to non-Britons in the eighteenth century. Within the confines of a thesis on Smollett, this specifically includes the perception of Scots by the English and British opinions on Catholicism; each of these issues was also bound up in questions of power and authority. Knowledge of English attitudes toward the Scottish allows the historian to ask the right questions about Smollett's own status as a Scottish Briton; in a different way, knowledge of larger British attitudes toward Catholics provides a useful context for Smollett's own writings on foreigners, as some of Smollett's most forceful observations and ruminations are about Catholicism in his Travels.

British attitudes toward other Europeans in the eighteenth century can be discovered from a variety of perspectives. Geoffrey Trease's 1967 The Grand Tour does so by compiling narratives of that common journey through Europe - most popularly

\footnotetext{
${ }^{12}$ Knapp, Doctor of Men and Letters, 82-84, 48.

${ }^{13}$ Knapp, Doctor of Men and Letters, 115.
} 
France and Italy - "in the words of the dictionary... 'as finishing touch to education.",14 Trease provides a basic foundation for understanding British reluctance to engage too much with the people they encountered on the road, citing one writer who said that a principle of the Grand Tour was "Not to spend more Money in the Country of our Natural Enemy [France] than is requisite to support, with Decency, the Character of an Englishman." ${ }^{15}$ But why was it necessary to spend as little as possible? After all, the Tour was an exciting adventure to most people who undertook it. The cast of characters which follows Trease's brief introduction to the idea of the Tour does illustrate this need to some extent, but it is necessary to look to more narrowly focused studies of the people and concepts that touring Britons encountered to truly understand the "necessity" of spending little.

\section{Richard de Ritter's “"This Changeableness in Character”” examines James} Boswell's own iteration of the Grand Tour. Citing earlier works by Chloe Chard and Michèle Cohen, de Ritter reminds the reader that "the transformative, and potentially transgressive, properties of the tour were most frequently associated with southern Europe." ${ }^{16}$ In other words, places like Italy and southern France were particularly dangerous to the traveler. This was not so in the sense of possible theft, assault, or any other petty crime one would associate with traveling: rather, the danger to British travelers was the effect going abroad could have on the Briton. De Ritter goes on to examine Dialogues on the Uses of Foreign Travel, written by Richard Hurd in 1764. One of Hurd's characters, Locke, concedes that "a young man may be polished indeed out of

\footnotetext{
${ }^{14}$ Geoffrey Trease, The Grand Tour (Chicago: Holt, Rinehart and Winston, 1967), 2.

${ }^{15}$ Trease, The Grand Tour, 13.

${ }^{16}$ Richard de Ritter, "This Changeableness in Character': Exploring Masculinity and Nationhood on James Boswell's Grand Tour," Scottish Literary Review 2:1 (2010): 24.
} 
his rusticity" by travelling outside of Britain; however, "if he have no better rule to go by, than the fashion of the place, where he lives, he may easily wear himself into a contrary defect, an effeminate and unmanly foppery." ${ }^{17}$ Spending too much time - or getting too comfortable - in a European setting could permanently damage the British character of the traveler.

For some, though, this change was desirable; de Ritter indicates that Boswell was one of them by excerpting this segment from Boswell's journal:

The Scotch tones and rough and roaring freedom of manners which I heard today disgusted me a good deal. I am always resolving to study propriety of conduct. But I never persist with any steadiness. I hope, however, to attain it. I shall perhaps go abroad a year or two, which may confirm me in proper habits. ${ }^{18}$

Boswell wanted to be changed by going abroad, as he felt his Scottish manner was not sufficiently polished. De Ritter attempts to explain Boswell's shame by defining it is "an aversion which suggests that the 'complete gentleman' formed upon the tour must efface any signifiers of national identity." 19 De Ritter comes very close to the mark here, but fails to build upon this foundation. Earlier in the article de Ritter does approach some of the issues of integrating the appellation Scottish within the larger British status that had come into being in 1707. However, his claim that Boswell sought to remove any national identifier does not connect well with his later assertion that Boswell's shame was "a manifestation of his regret for the loss of 'principle and spirit of patriotism' that resulted from the act of Union. ${ }^{, 20}$ If Boswell was embarrassed by his Scottish roots but did not

\footnotetext{
${ }^{17}$ Richard Hurd, Dialogues on the Use of Foreign Travel; Considered as a Part of an English Gentleman's Education: Between Lord Shaftesbury and Mr. Locke (London: A. Millar, 1764), 105, quoted in de Ritter, "“This Changeableness in Character'," 26.

${ }^{18}$ Frederick A. Pottle, ed., Boswell's London Journal, 1762-1763 (London: Heinemann, 1950), 272, quoted in de Ritter, “'This Changeableness in Character'," 26.

${ }^{19}$ De Ritter, “"This Changeableness in Character'," 36.

${ }^{20}$ De Ritter, “"This Changeableness in Character'," 36. The internal quotation is from Pottle, ed., Boswell's London Journal, 266.
} 
want to assume the mantle of Briton, then what did he seek? De Ritter's admission that Boswell was simply still confused about who he was when he returned to Britain is not particularly helpful. ${ }^{21}$ This problem does, however, highlight the struggle to define the boundaries of national identity that go along with trying to understand Tobias Smollett and provides guidelines of consideration.

Michèle Cohen's earlier article on the Grand Tour and its implications for British masculinity also examines the danger of travel - especially to France. Cohen highlights the paradox of traveling out of Britain: although the Tour was intended to be the finishing component of a young man's education - and therefore "make him a man" - as seen in Hurd's Dialogues the Tour could actually make males more effeminate. ${ }^{22}$ Such a danger casts the prospect of a Tour through Europe (particularly the French component) as a feminizing journey, one which is seriously opposed to inherent British masculinity. ${ }^{23}$

Cohen's discussion of the desire to travel tinged with the fear of becoming "too foreign" is a significant component of understanding the traveler's mindset; however, she leaves the reader with more questions that she answers when exploring the presence of men in Britain who gloried in what they had seen and learned on the Tour. These men were known as "Macaronies." They were largely "young noblemen who had been abroad ...who...saw themselves as representing 'the standard of taste in fashion as well as in polite learning." ${ }^{24}$ These were men who loudly boasted of their experiences and displayed their worldliness for all to see: one thinks of an acquaintance who has been to a foreign place and speaks of nothing of that place upon return. Cohen puzzles her reader

\footnotetext{
${ }^{21}$ De Ritter, “"This Changeableness in Character'," 35.

${ }_{22}$ Michèle Cohen, "The Grand Tour. Language, National Identity, and Masculinity," Changing English 8:2 (2001): 132.

${ }^{23}$ Cohen, "The Grand Tour," 135.

${ }^{24}$ Cohen, "The Grand Tour," 132.
} 
by later projecting what she perceives to be the Macaronies' "real" motivation for showing off their travels:

What the Macaronies did was to parody the Grand Tour and its aims. With a kind of post-modern irony, they highlighted its contradictions and even its absurdity - reflected in their eccentric dress: towering wigs topped by tiny hats, very tight-fitting clothes with huge buttons. ${ }^{25}$

Cohen unfortunately offers no evidence for this apparent mocking of the Tour - what sense does it make that these representatives "of taste in fashion as well as in polite learning" were actually satirists? One can reasonably imagine that perhaps these men were mocking the Tour and simultaneously showing off their wealth by wearing absurd clothing: "I know this looks ridiculous, but I can wear it because I' $m$ rich and went on the Tour." If this is the case, Cohen offers no indication of it, and so her treatment of Touring Britons back in the homeland offers an opportunity for further clarification. More importantly, her discussion of the effects on travelers feared by Britons relates to some of the complaints that Smollett expressed during his time in France.

As the second main stop on the Grand Tour, Italy played host to a number of British tourists during the eighteenth century; the danger of corruption there was no less palpable than anywhere else. Writing on specifically Scottish visitors to Venice, Iain Gordon Brown produces an image of the city as a place of great moral danger but also the revealing platform of Scottish social backwardness. Brown says of the city "All in all, Venice was a most un-Scottish place, yet visits to the city seem often to have revealed in the Scottish character a good measure of hypocrisy and censoriousness. ${ }^{26}$ Venice apparently brought out the worst in Scots, both in their sneering attitude toward things

\footnotetext{
${ }^{25}$ Cohen, "The Grand Tour," 132.

${ }^{26}$ Iain Gordon Brown, "Water, Windows, and Women: The Significance of Venice for Scots in the Age of the Grand Tour," Eighteenth Century Life 30:3 (2006): 4.
} 
they found distasteful and in their behavior when they decided to misbehave. Samuel Johnson wrote that "if a young man is to run wild, and must run after women and bad company, it is better that it should be done abroad as, on his return, he can break off such connections and begin at home a new man. ${ }^{, 27}$ To put it more directly: if a man was going to do these sorts of unpleasant things, better to do them on the Continent. This is not to suggest that Venice held no other appeal for travelers; Brown writes that one traveler "could see that even an ancient and picturesque Scottish river bridge was but a 'mere bauble' compared with the great and beautiful Rialto." 28

Despite these sorts of attractions, at the end of the day Venice was still no Edinburgh or Glasgow; "Venice did seem to many a place so odd, and possessed of characteristics that might be found so unattractive, or even so downright unpleasant, that the spell was easily and soon broken. ${ }^{, 29}$ Brown's depiction of Venice ultimately portrays the city as something of a playground for visiting Scots. In the city they could behave as they wished and then look down their noses after remembering their "true," more sober selves. A useful addition to Brown's analysis would have been some discussion on a specifically Scottish version of the "Macaronies" mentioned above: what of the Scots who gloried in Venice's vices and took them back home, not changing as Dr. Johnson would have them do? Answers to these questions would greatly add to the understanding of Scottish (and more broadly British) perceptions of Venice.

Rosemary Sweet has authored two articles on British perceptions of Italy, one each on Florence and Rome. A thread connecting both articles is the British sense of

\footnotetext{
${ }^{27}$ Originally quoted in J. H. Plumb, Men and Places (London: Cresset, 1963), 59, reprinted in Brown, "Water, Windows, and Women," 19.

${ }^{28}$ Brown, "Water, Windows, and Women," 42.

${ }^{29}$ Brown, "Water, Windows, and Women," 43.
} 
superiority, whether through appreciating those positive elements of the cities which had British counterparts or by the acknowledgment that a city had abandoned some part of its identity that Britain successfully maintained. In Florence, especially by the end of the eighteenth century, British tourists were impressed by the city's "commercial and manufacturing wealth," which "had permitted patronage on a scale which even the wealthiest of the landed elite were bound to admire." ${ }^{30}$ Additionally, Britons appreciated the efforts of Duke Leopold, who had made Tuscany more similar to Britain "with his agricultural reforms, suppression of monasteries, codification of the law, [and] abolition of excessive ceremony and ritual." Indeed the solid "middling class" Briton could appreciate these efforts deeply, as they made Florence appear "more British" than other Italian cities.

Sweet acknowledges that appreciation of Florence has to be considered in light of the demographics of tourists: as the century wore on, visitors to the city became less aristocratic on the whole. Specifically,

Travellers' perceptions of Florence underwent a significant reorientation during the long eighteenth century, in keeping with changes in the composition of the tourist body and the different intellectual and social agendas of both the travelers and those who represented the city to them as guides and hosts. ${ }^{32}$

This is an accurate summary of who went to Florence, but it leaves out half the question: what about later aristocratic visitors and earlier non-elite tourists? What about men like Tobias Smollett, who may have claimed an aristocratic lineage but no longer enjoyed a massive disposable income? This is the only weakness in an otherwise excellent

\footnotetext{
${ }^{30}$ Rosemary Sweet, "British Perceptions of Florence in the Long Eighteenth Century," The Historical Journal 50:4 (2007): 838.

${ }^{31}$ Sweet, "British Perceptions," 843.

${ }^{32}$ Sweet, "British Perceptions," 859.
} 
overview of Florentine tourist history and one which an examination of Tobias Smollett may help to answer.

Sweet's analysis of visitors to Rome exposes the "custodian" instinct in those tourists who saw some of the city's greatest monuments. British tourists recognized the glory of the city but felt that by the eighteenth century its days of splendor were over due to "the damage inflicted on antique monuments by the early Christians, during the civil wars of the medieval era or in more recent urban improvements." ${ }^{33}$ Of particular abhorrence to Protestant British visitors was the use of splendid buildings and sites for Catholic religious purposes - in the visitor's mind, only the "proper" treatment a nonCatholic could give the place was fitting. ${ }^{34}$ Ultimately the negative view of Rome was one similar to the feelings of a parent toward a delinquent child: such potential had been there before, but it had been squandered in the meantime. Most important to this feeling was Britain's increasing stature on the world stage, as Sweet highlights the easy comparison made by travelers between the past glory of imperial Rome and the growing glory of the British empire. ${ }^{35}$ Tobias Smollett was no stranger to these feelings of bygone splendor, and that thread will be picked up below.

Given Tobias Smollett's Scottish roots it would be useful to mention some of the scholarship on the attitude of the English toward the Scottish during the eighteenth century. John Stuart (Lord Bute), prime minister from 1762 to 1763 , is a good focus for this sort of discussion as his high profile and Scottish heritage have allowed historians access to a variety of sources on anti-Scottish sentiment in eighteenth-century England.

\footnotetext{
${ }^{33}$ Rosemary Sweet, "The Changing View of Rome in the Long Eighteenth Century," in Journal for Eighteenth-Century Studies 33:2 (2010): 149-150.

${ }^{34}$ Sweet, "The Changing View of Rome," 151.

${ }^{35}$ Sweet, "The Changing View of Rome," 159.
} 
Although his "Misfortunes of Lord Bute" examines broader themes of political argument during the eighteenth century, John Brewer does spend some time on Bute's heritage. Brewer illustrates just how unpopular many English held the Scottish to be by placing them lower on the social scale than even the Jewish population of London, those non-Christians who had been subjected to so much suffering throughout their European history. But why despise the Scottish so much?

[The Scot] was poorly fed...spoke unintelligibly and suffered from that unpleasant but characteristically Scottish disease, the itch. Although thought to be subservient by nature, he was also deemed totally untrustworthy...the Scots were supporters of the Stuart dynasty...friends of France and believers in the Catholic faith. They supported standing armies; indeed, had heavily infiltrated the higher ranks of the British land forces. In sum, they appeared to approve all the tenets of despotism. ${ }^{36}$

Quite the damning description. Yet this was, according to Brewer, how many English men and women viewed their northern neighbors-cum-compatriots. Bute's Scottishness in particular became a self-reinforcing handicap. His political opponents first used Bute as an example of all that was wrong with Scotsmen, and then used all that was wrong with Scotsmen as an example of Bute's inadequacies. In other words, Bute was like the Scots and the Scots were like Bute. Indeed hatred of the Scots was so severe that some who could afford it took speech lessons to soften their brogue and made their names appear more English. ${ }^{37}$

Brewer also discusses the constitutional elements of Bute's premiership, suggesting that attacking Bute's heritage was simply another way to hound a man who many felt was not playing by the rules. Some believed Bute to have undue influence on George III; thus, his holding of the prime minister's post allowed him "to subvert the

\footnotetext{
${ }^{36}$ John Brewer, "The Misfortunes of Lord Bute: A Case-Study in Eighteenth-Century Political Argument and Public Opinion," The Historical Journal 16:1 (1973): 19-20.

${ }^{37}$ Brewer, "The Misfortunes of Lord Bute," 21-22.
} 
balance of the constitution in order to further his own autocratic ends. ${ }^{38}$ As will be seen in other contexts below, the issue of power was often in question during the eighteenth century - often to the point that apparently unrelated elements, like point of origin, were attacked.

In all discussions of an outcast or oppressed group, it is necessary to also discuss members of those groups who may find better integration into larger society. Brewer unfortunately does not provide this sort of information, and a mention - however brief of Scots beyond high-fliers like Bute and his circle of allies who did find success in England (and London in particular) would have provided balance to his explanation of anti-Scottish sentiment. Despite his reputation as a relatively unpopular prime minister, Bute proved that not all English men and women felt that Scots were filthy, unintelligible oafs. Even if Smollett's social circle was predominantly Scottish, historians and literary critics would know very little of him now if he had achieved no integration into British society.

Alexander Murdoch’s essay “Lord Bute, James Stuart Mackenzie, and the Government of Scotland" on Bute and his brother further develops the idea of Bute's usurpation of rightful power (or, at the least, his abuse of position). Murdoch presents another aspect of anti-Scottish opinion that illuminates differences still perceived after the 1707 Act of Union between England and Scotland:

...most of the English viewed Scots as crypto-Jacobite traitors, strangers to the principles of English law and liberty, who were exploiting the Union for their

\footnotetext{
${ }^{38}$ Brewer, "The Misfortunes of Lord Bute," 23. One of the most memorable methods of lampooning Lord Bute was to create some image of a boot with a petticoat - whether on paper or by literally parading the two through the streets - to rather indiscreetly suggest that Lord Bute's relationship with George III's mother extending beyond the limits of propriety. See 6-7.
} 
own gain at the expense of honest English subjects whose nation was the comerstone of the king's dominions. ${ }^{39}$

Murdoch's analysis points to a United Kingdom not quite united in everyone's mind.

Most importantly, much anti-Scottish feeling claimed that Bute and his fellow Scotsmen "would not respect the constitution." ${ }^{, 0}$ Out of Murdoch's analysis one can draw the conclusion that those opposed to Scots in power were concerned not so much with Scottish people being Scottish as they were with Scottish people being "not-English." Adam Rounce briefly mentions this problem in an article on Wilkes and Churchill by highlighting the hesitancy of one Englishman to call himself British: as the Scots were so happy to call themselves British, this man wanted nothing to do with such an appellation and thus preferred to stick with "English."

With these accounts of Bute it must be borne in mind that he was but one lightning rod of anti-Scottish sentiment, and the authors above dealt largely with bigotry focused specifically on one important man. Even with this caveat the challenges faced by Bute can be taken as indicative of general anti-Scottish feeling during the century, and that bias introduces significant questions of constructing a British identity. That larger identity will be treated in the following chapter and discussed in greater detail in relation to Smollett's Travels later.

The "internal" dynamics of constructing a British identity were matched by an outward-looking perception of non-British Europeans. Robert and Isabelle Tombs's That Sweet Enemy studies the "Natural Enemy" of which the Grand Tourist spoke above.

\footnotetext{
${ }^{39}$ Alexander Murdoch, "Lord Bute, James Stuart Mackenzie, and the Government of Scotland," in Lord Bute: Essays in Re-interpretation, ed. Karl W. Schweizer (Leicester: Leicester University Press, 1988), 117.

${ }^{40}$ Alexander Murdoch, "Lord Bute," 138.

${ }^{41}$ Adam Rounce, "'Stuarts without End': Wilkes, Churchill, and Anti-Scottishness," Eighteenth-Century Life 29:3 (2005): 34 .
} 
Although it treats some other areas of social perception, the main thrust of their monograph is the British fear of French power and authority. Proud "owners" of a parliamentary system, during the eighteenth century the British understood that "France was still the European giant. Its monarchy seemed more powerful and stable than that of Britain, subject to perennial party quarrels and disputed succession." 42 In terms of the frequent military conflict in the eighteenth century, the structure of French authority terrified the British; as the Tombses put it, "francophobia expressed fear of absolutism and resentment of snobbery." Fears of absolutism were tightly bound up with fears of religion, too, as "British defenders of Protestantism attacked the Bourbon monarchy as the enemy of religion and political liberty, and the manipulator of superstition - the strategy summed up as 'Popery.",43 The Tombses pull back slightly from this, however, by continuing with

religion was not the basic cause of cross-Channel polarization. The British were always more afraid of Versailles than Rome. Moreover, Catholics and Protestants were themselves bitterly divided...Anglicans and Scottish Episcopalians, faced with troublesome Dissenters, could for their part see merits in French Catholicism. ${ }^{44}$

This statement raises a number of questions which must be dealt with the later. For now it is sufficient to say that with Rome being the "capital" of Catholicism it is not necessarily true that the British always feared Versailles more than Rome. Furthermore, the division among Catholics and Protestants is not in itself a strong enough proof that antiCatholicism was not such a key element of British identity. This is not to completely refute the Tombses; however, their decoupling of power and religion goes too far.

\footnotetext{
${ }^{42}$ Robert and Isabelle Tombs, That Sweet Enemy: The French and the British from the Sun King to the Present (New York: Alfred A. Knopf, 2007), 29.

${ }^{43}$ Tombs, That Sweet Enemy, 94-95.

${ }^{\$ 4}$ Tombs, That Sweet Enemy, 95.
} 
Smollett's own commentary on Catholicism as he traveled through Europe will show just how integrated these issues were, at least in the mind of one Scotsman.

John Miller brings this connection of power and religion "home" to Britain with James II, who provides provides a powerful focus of British anti-Catholicism. Opposition to James was expressed not only on religious grounds - there were considerable political and authority implications, as well. Miller writes that James himself associated Protestantism with rebellion against legitimate authority; in terms of political rebellion, many British Protestants would have agreed with him as by the late seventeenth century "the connexion of Catholicism with absolutism was seen as axiomatic." ${ }^{\text {"45 }}$ Miller shows that the sparks of this disagreement were eventually fanned into a roaring fire; James rather unwisely said to Parliament in a speech

I will keep my word and undertake nothing against the religion which is established by law, unless you first break your word to me. But if you do not do your duty towards me, do not expect that I shall protect you. You may be sure that I shall find means to do my business without you. ${ }^{46}$

These were unpalatable words to a Protestant people, distasteful to the point of getting rid of James by 1688 . Here, then, lay the most immediate origins of eighteenth-century antiCatholicism.

Miller's work understandably limits itself almost entirely to high-level elements of power - the relationship between king and king, king and pope, and king and people. However, issues of power extended below these levels as well. In her "“A Trial for the Patience of Reason"' Clare Haynes spends several paragraphs examining the power relationship between priest and people and its perception among the British. While eighteenth century absolutist states were often associated with Catholic civic rulers,

\footnotetext{
${ }^{45}$ John Miller, James II (New Haven: Yale University Press, 2000), 58, 66.

${ }^{46}$ Miller, James II, 136.
} 
apparent oppression of the populace could also take place on the part of the clergy.

Haynes quotes Robert Gray, eventually Bishop of Bristol, saying

In Gray's view, the poverty of the Roman countryside was due, rather concisely, to 'castration, celibacy, and bad government. It was Catholicism that was to blame, and Gray would later argue, in his opposition to Catholic emancipation, that the poverty of Ireland had the same root cause: the Catholic religion. ${ }^{47}$

Furthermore, Haynes writes

widespread belief among Protestants that celibacy and avowed poverty were at least mistaken, even sinful, corruptions of a good religious life, and the idea that Catholic religious were hypocritical and corrupt in their morals, as well as their devotions. ${ }^{48}$

For Gray the power that Catholic clergy held over lay men and women was the source of suffering in non-British lands. Haynes's article was presumably not written with Tobias Smollett specifically in mind; however, these are issues of power with which Smollett directly grapples.

The significance of Catholicism to a discussion of eighteenth-century Britain cannot be overstated, as it extended far beyond purely religious grounds. In Italy and the Grand Tour, Jeremy Black writes "anti-Catholicism was the prime ideological stance in eighteenth-century Britain." In general terms that summarize the above authors, "Catholicism was equated with autocracy, drew on credulity and superstition, and led to misery, clerical rule, and oppression." ${ }^{, 49}$ These elements are significant to Black's construction of Britons as a nation believing themselves to be advanced above and beyond others - in this case, Catholic Italians. The British were able to vent their frustrations with Catholicism through criticisms of Italy because that country was such an

\footnotetext{
${ }^{47}$ Clare Haynes, “'A Trial for the Patience of Reason'? Grand Tourists and Anti-Catholicism after 1745," Journal for Eighteenth-Century Studies 33:2 (2010): 199.

${ }^{48}$ Haynes, “'A Trial for the Patience of Reason,"” 200.

${ }^{49}$ Jeremy Black, Italy and the Grand Tour (New Haven: Yale University Press, 2003), 166.
} 
important component of the eighteenth century's Grand Tour. But why would a people so viscerally against Catholicism venture into its very geographical heart?

The answer, according to Black, lay in the aforementioned British fascination with a time long past, showing veneration "for republican relics such as Lucca and San Marino." ${ }^{, 50}$ More overtly, "Italians were unfit to inherit their classical past, and it was reasonable, indeed necessary, for it to be appropriated by the 'civilised' British." ${ }^{\text {II }}$ It was not eighteenth-century Italy which attracted British tourists: rather, it was Italy's past that Britons wanted to see.

Black's treatment of Britons in Italy provides a wealth of information and goes a long way toward explaining why the British were so enamored with a country containing a religion so deeply abhorrent to many Britons. Unfortunately, he does not illustrate a connection between Catholics in Italy and Catholics in Britain. True enough the book is about Italy, but there was a reason the Protestant British feared Catholicism. It was not confined only to Italy, as most of the French were Catholic; furthermore, those Britons who were Catholics were looked upon with suspicion. Surely British opposition to Italian Catholicism did not stem only from a paternalistic sense of disgust and superiority - there was a danger there, as well. Similarly, Tobias Smollett would not have offered such deepfelt and biting commentary on Catholicism had he not some existing reason do to so.

Colin Haydon's essay “'I love my king and my country, but a Roman Catholic I hate'" fills in the gap left by Black. Whereas Black almost exclusively examines Britons criticizing Italian Catholicism while in Italy, Haydon takes a larger view and compares Britain to the rest of continental Europe as a whole. In fact, Haydon writes that "the main

\footnotetext{
${ }^{50}$ Black, Italy, 147.

${ }^{51}$ Black, Italy, 159-160.
} 
contribution of anti-Catholicism in the Georgian era was to construct the European continent as fundamentally alien. ${ }^{.52}$ In Haydons view, then, Catholicism was the main reason that Continentals were so different from the British. This difference was perceived not only across the Channel but within the British Isles, as well - and this "home" Catholicism was that much more worrisome. ${ }^{53}$ The eighteenth century was a period of particularly intense anti-Catholicism, as the century contained such long periods of warfare between rival Protestant and Catholic countries. Haydon writes that Britons felt especially vulnerable to the Catholic threat during the high-stress times of war and "some believed they [British Catholics] might come out in open rebellion." 54

Haydon makes an important point about the nature of British anti-Catholicism, an element that complicates its study:

One must not assume that the intensity of anti-popish feelings was uniform. It was especially strong among certain groupings - for instance, non-conformists, methodists [sic], and rational dissenters - and...soldiers and sailors were prominent among "No Popery" rioters. Anti-popery was geographically patchy, seeming marked in places where Marian martyrs originated, were captured or burnt, and in coastal regions, with folk memories of the French and Spanish threat. ${ }^{55}$

Such a distinction shows the nuances of British religious sentiment, but even with these distinctions in mind one must remember a point made by several scholars: British Protestantism, whatever its flavor, was unitary in the fact that it wasn't Catholic. ${ }^{56}$

\footnotetext{
${ }^{52}$ Colin Haydon, "'I love my king and country but a Roman Catholic I hate': Anti-Catholicism, Xenophobia and National Identity in Eighteenth-Century England," in Protestantism and National Identity: Britain and Ireland, c. $1650-$ c. 1850 , ed. Tony Claydon and Ian McBride (New York: Cambridge University Press, 1998), 33-34.

${ }^{53}$ Haydon, "Anti-Catholicism," 37.

${ }^{54}$ Haydon, "Anti-Catholicism," 44-45.

${ }^{55}$ Haydon, "Anti-Catholicism," 50.

${ }^{56}$ Among those scholars is Jonathan Clark, who will be briefly mentioned below.
} 
This review has attempted to highlight the relative inadequacy of extant historiography on Tobias Smollett when approached through the lens of eighteenthcentury British identity. Smollett's status as a "non-alien alien" in the British capital (and later abroad) does not simply indicate the total integration of all non-English people into the nascent United Kingdom; his biographers have not yet clarified exactly what effect on Smollett the vagaries of British identity exerted. Put another way, the question "How was Tobias Smollett British, and why did he feel this way (or not)?" has yet to be fully answered. To a certain degree scholars examining other, tangential aspects of British identity provide the tools with which to examine Smollett. As discussed here, issues of religious opposition, the perception of continental Europeans by Britons, and the integration of the Scottish into British life are all helpful pointers to a richer image of Tobias Smollett. To that end, Smollett's Travels through France and Italy will be analyzed in detail below by implementing these tools in an attempt to uncover an image of the man obscured by centuries of less-than-stellar renown.

In the meantime, two other perspectives have broken onto the scene in recent decades which also demand attention in any thesis exploring British identity. The first concerns the actual definition of "Britishness" - what made a Brit just that - ushered in by Linda Colley and subsequent scholars from the late twentieth century. The second focuses upon the Atlantic world, a new subject of historical inquiry that no few scholars have felt has revolutionized understanding of the peoples and places surrounding that ocean. Each of these concepts will be examined below, and this thesis will outline the ways in which they are helpful in some places and irrelevant in others when considering Tobias Smollett, the eighteenth century, and the British. 
Who Were the British?

The history of the British as a national group is as varied as that of any other: who was British and how they came to be thought of as such was a complex and at times bewildering process. The enormous number of books and essays that have been written on "the British" are all based on some particular assumption of what exactly "British" means, but that definition is not always made clear. The seminal work that has spawned a great number of subsequent studies into British historical identity is Linda Colley's Britons. When the book was published in 1992, Colley wrote that she was attempting to define who exactly the British were during the eighteenth century by

uncover[ing] the identity, actions, and ideas of those men and women who were willing to support the existing order against major threats their nation faced from without, to establish exactly what it was these Britons thought they were being loyal to, and what they expected to gain from their commitment. ${ }^{57}$

These elements, then, were what defined the British in the eighteenth century. The concepts of external threats, loyalty, and the benefits of Britishness are explored in detail below as examples of what made a Briton a Briton.

Colley speaks to Peter Sahlins's assertion that national identity is determined by who a people is not, describing the post-1707 British by saying "they came to define themselves as a single people not because of any political or cultural consensus at home, but rather in reaction to the Other beyond their shores." 58 In other words, "nonBritishness" defined "Britishness." The most explicit example of this negative selfdefinition was Protestantism, on which Colley elaborates in Britons. Her book extends

\footnotetext{
${ }^{57}$ Linda Colley, Britons: Forging the Nation 1707-1837 (New Haven: Yale University Press, 1992), 1. ${ }^{58}$ Colley, ibid, 5-6.
} 
far beyond considerations of religion, entering the realms of politics, gender dynamics, and military power; it is sufficient to say here that Colley's work has provided a foundation upon which numerous other scholars have interpreted the meaning of Britishness.

One of those scholars is Krishan Kumar, who has written extensively on the relationship between British imperialism and specifically English identity. His work is also useful for examining the complicated question of "priorities of identity": if one claims membership in multiple groups, in what order does that person rank their identity? ${ }^{59}$ Such a question is significant to a study of the British Empire, which had an extremely diverse administration and membership. Kumar addresses this question in his influential "Empire and English Nationalism." While acknowledging the presence of multiple ethnic identities in the administration of British imperialism, Kumar reminds the reader that "it was predominantly the English who were in command. ${ }^{, 60}$ Building on Ben Wellings's earlier work (approached below), Kumar explains that "to govern the empire one needs to make as many of these peoples as possible feel that they belong, that the empire is as much theirs as it is that of those who originally created it." ${ }^{, 61}$ This is a complex objective; after all, with the majority of British imperial administrative and military leadership composed of English men, how is it possible to make non-English imperial subjects feel any sense of ownership? The English succeeded in doing so by executing a de-emphasization of their own national identity in favor of a more encompassing British identity. In Kumar's own words,

\footnotetext{
${ }^{59}$ For an example of the mechanics of this "identity shuffle," see Colley, Britons, 159.

${ }^{60}$ Krishan Kumar, "Empire and English Nationalism," Nations and Nationalism 12 (2006): 5.

${ }^{61}$ Kumar, "Empire and English Nationalism," 6.
} 
[i]t was a marked feature of Britishness that, of all the nations of the British Isles, it was the English who most subordinated their identity to it, to the point where over time the difference between the English and the British became elided. This of course reflected the fact that it was the English who had the highest stake in the venture. To have celebrated their own English identity, as the creators and directors of Great Britain, would have been impolitic in the extreme. Most English statesmen recognized that. So too, perhaps even more, did the monarchy, which especially in the person of Victoria made a conscious effort to tie together the various peoples of her kingdom by cultivating their ways and finding opportunities to dwell among them. ${ }^{62}$

In a (successful) attempt to create the perception of some level of "common ownership," the numerically dominant English allowed their particular national identity to be absorbed within a greater, specifically British identity. In this way, the English majority became more palatable due to the presence of an overarching British group label. Of course this approach to an English-style Britishness assumes a considerably well-defined "imperial agenda" on the part of the English with clear objectives of Anglicization. One may rather more safely conclude that any imposition of Englishness on newly-minted Britons was the result of more subtle and involuntary cultural assimilation rather than any overt effort on the part of the English.

This expansive definition of what made one British provides some explanation for the elision in thinking about all inhabitants of the island comprising England, Wales, and Scotland as "the English". As Colley makes clear, non-English members of the post-1707 Union - the Scottish, the Welsh, and the Irish after 1801 - were able to join the English in creating a British identity that transcended previously-held local conceptions of whom one was. Such transcendence, Colley indicates, did not necessarily entail the disappearance of a separate national membership. In fact, "it was common to think in terms of dual nationality, not a single national identity" in a manner vaguely similar to

\footnotetext{
${ }^{62}$ Kumar, "Empire and English Nationalism," 8.
} 
the way in which citizens of the United States may claim identity as inhabitants of a particular state and the republic at large. ${ }^{63}$

English assimilation into Britishness was not, of course, altruistic. Ben Wellings highlights the nature of the British Empire in his earlier "Empire-nation: National and Imperial Discourses in England," specifically showing that "this situation [downplaying English identity] gave Englishness and Britishness much of the same character...making the terms 'English' and 'British' almost synonymous - at least for the English." ${ }^{64}$ Thus, in a paradoxical yet functional manner, the English accomplished some degree of cultural dominance by willfully eliding the two terms.

Colley provides the important clarification that this cultural dominance came about not only through covert subterfuge or underhanded assertions of English superiority: the members of the so-called "Celtic fringe" knew that the key to real power and influence lay in connection to English families. Thus impoverished (yet still wellconnected) English aristocrats sought out wealthy Scottish, Welsh, and Irish women to inject capital into their estates; in return, those families on what Colley calls the "periphery" of the British Isles gained access to the corridors of power. ${ }^{65}$

It is rather easy to see this process as sacrificing peripheral identity for membership in an elite social stratosphere dominated by English culture, so that one must renounce Scottishness for Britishness; however, in addition to the above-mentioned

\footnotetext{
${ }^{63}$ It is worth noting here that not all people living in the British Isles thought of themselves as British or even wanted the concept of Britishness to exist; see Colley, Britons, 372-373: "Far more nineteenth-century Britons that is usually recognized lived in places exactly like Heyshott [a small village in Sussex], cut off for most of the time by custom, poverty, ignorance and apathy."

${ }^{64}$ Ben Wellings, "Empire-nation: National and Imperial Discourses in England," Nations and Nationalism 8 (2002): 95 .

${ }^{65}$ Colley, Britons, 159-160. Entry into the political structure of Great Britain was given to Scotland with the Union of Scotland Act 1706, which provided for 45 Scottish representatives in the House of Commons and 16 peers in the House of Lords.
} 
concept of "dual nationality," it should be noted that plenty of English aristocrats gained the title of "Briton" not merely through virtue of English dominance but by actual possession of non-English property. Colley cites the case of Edward Lovedon, a Berkshire landowner who came into the ownership of property in Cardiganshire, "thereby transforming him from a small-scale English squire into a British landowner." ${ }^{\prime 66}$ This reinforces the suggestion that entering the ranks of a group identifying itself as British did not entail renunciation of previously-held local identity. One was able to attain membership in groups both particular (local) and general (Union-wide).

Such crossings of national boundaries in an effort toward increasing personal wealth and prestige modify the construction of British identity as one "secretly" achieved along English-only lines: true, the English allowed their dominant culture to become less overt, downplaying Englishness in favor of Britishness. But if Lovedon proves anything, it is that he could achieve success by looking specifically outside of what England had to offer. In Lovedon's case, additional wealth lay beyond English borders. He thus went to Wales to increase his estate. Such border crossing bears witness to the creation of not one, not two, but three (or even more) distinct identities for some inhabitants of the British Isles: Lovedon was an Englishman, an owner of Welsh land, and the subject of a British monarch. What if he had owned additional property in Scotland or Ireland? Could we safely say that he assumed even more "identities" by such territorial ownership?

The answer must be an emphatic "yes." This is not to suggest that British identity is so fluid that it cannot be defined in a meaningful way. By way of Colley's contention that owning Welsh land made Lovedon a British landowner, one understands that each particular territory contributed to an additive nature of British identity - in Lovedon's

\footnotetext{
${ }^{66}$ Colley, Britons, 157.
} 
case, English heritage combined with Welsh landownership created a Briton. In what is not intended to be an obfuscatory web of identifiers, Colley's illustration suggests that maintaining any sort of attachment to multiple constituent parts of Britain conferred additional identities upon those stakeholders. True enough, Edward Lovedon was not Welsh; however, he was British, and as Wales was (and is) a crucial component of Great Britain one can safely assume that his ownership of Welsh property added to the list of identities he maintained.

"Confound their politics / Frustrate their knavish tricks / On Thee our hopes we fix / God save us all": Protestantism

It is important to follow up here on another piece of "home identity," as it were, to serve as a foundation upon which all related imperial (and Atlantic) activities took place. As discussed above in the context of Continental Europeans and the Grand Tour, a basic building block of Britishness in the eighteenth century was Protestant religion: Colley's Britons takes religious tension a great many steps forward by stating that "Protestantism

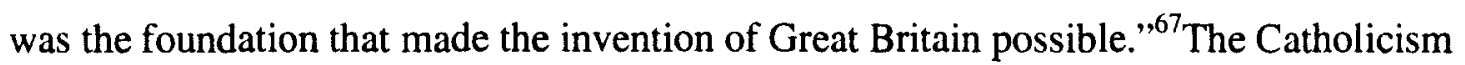
of the majority of the French and Spanish evoked fearful memories for the British (especially the English), both imagined and otherwise: Fawkes had nearly succeeded in destroying Parliament and killing James I; the Catholic queen of Charles I had dragged England into civil war; and Catholics, it was rumored, had been responsible for the 1666 London Fire. Most proximate to the period of this paper, Charles Edward Stuart had led the Jacobite invasion that was put down at Culloden in $1745 .{ }^{68}$ Even the few examples of

\footnotetext{
${ }^{67}$ Colley, Britons, 54.

${ }^{68}$ Colley, Britons, 20.
} 
disasters feared to have been caused by Catholics touched all parts of British society - to British Protestants fearful of Catholics, no one was safe.

The questions of power and sovereignty as previously mentioned had strong historical roots by the eighteenth century. Theoretically, Catholic monarchs before and during that century held power only through the approval of the Bishop of Rome. The exceptions to this general rule are numerous; the power struggles that attended those exceptions formed some of the most significant events in European history, Henry VIII's assumption of status as head of the English Church being one of the foremost. It is also useful to recall Elizabeth I's frustration with Pius V after the pope's attempt to demand an explanation for the queen's religious policies and issues of sovereignty. In his Empire and Order, James Muldoon highlights Elizabeth's specific position as she claimed "the pope was attempting 'to bring this realm and the imperial crown thereof...into the thralldom and subjection of that foreign, usurped, and unlawful jurisdiction, preeminence and authority claimed by the said see of Rome...",69 Even setting theological questions aside, Catholicism was dangerous: with the pope's approval of any given monarch, the threat to sovereignty was clear. England (later Britain) stood in direct contrast to the French, whom Rome so clearly ruled via the Bourbon king in the minds of many Protestants.

None of this is to suggest that Protestantism was the only reason that Britons felt antagonistic toward the French. It was necessary to define the French as "Other" for several reasons of competition, both military and economic. Those non-religious aspects of French power presented enough of a challenge to the British on their own; the overt Catholicism of the French, however, necessitated an equally prominent Protestant

\footnotetext{
${ }^{69}$ James S. Muldoon, Empire and Order (New York: St. Martin's Press, 1999), 130.
} 
response. Aside from a few generously-minded individuals able to separate personal religion from the rest of a nation's endeavors, the great majority of Britons looked across the English Channel - yes, indeed, the English Channel - and saw the Whore of Babylon poised to strike at any moment.

It is important to note that taking Protestantism as a defining aspect of Britishness went beyond the home islands. While defining the nation as Protestant was significant for purposes of maintaining that safe "home" identity, non-Catholic religious belief was significant in projecting Britishness - or at least some aspect of it - into the eighteenthcentury empire. While scholars debate precisely what form that projection assumed or the motivations for it, there is general agreement that Protestantism coupled with evangelization played an enormous role in spreading some sense of British identity. In his Anglicanism and the British Empire, c. 1700-1850, Rowan Strong recalls that although "Colley has been criticized, not least by [Jonathan] Clark, for overlooking the divisions within British Protestantism," historians such as Tony Claydon and Ian McBride have concretely established "that there was a close link between religion and national identity. ${ }^{, 73}$ In other words, even though British Protestantism may not have been as unified as Colley suggests, the connection between religion and identity was significant. ${ }^{74}$ That connection served to weaken the barriers between denominations of British

\footnotetext{
${ }^{73}$ Rowan Strong, Anglicanism and the British Empire, c. 1700-1850 (New York: Oxford University Press, 2007), 20-21. The above-mentioned works in Strong's historiographical introduction are Jonathan Clark's English Society 1660-1832: Religion. Ideology, and Politics during the Ancien Regime and Tony Claydon and Ian McBride's "The Trials of the Chosen Peoples: Recent Interpretations of Protestantism and National Identity in Britain and Ireland" in Protestantism and National Identity: Britain and Ireland c. 1650-c. 1850. ${ }^{74} \mathrm{~A}$ particularly fascinating example of this lack of religious uniformity is the Reverend Thomas Wren, a dissenting minister who spent a great deal of time and money on American prisoners of war during the War for Independence. Wren is illustrative of the divisions within British popular opinion on the war; his example, however, and his mindset of serving the American prisoners as something along the lines of national cousins point to the understanding of many Britons that the war was civil in nature and not between two separate powers.
} 
Protestantism: while Protestant congregations may have disagreed with each other on some issues, most were united in anti-Catholicism. The crucial component of British Protestant identity was not necessarily adherence to Anglicanism but opposition to Catholicism (although Dissenters were not always accorded equality in civic life).

As briefly mentioned by Strong, the linkage of religion and identity assumed an imperial format in mission societies such as the Society for the Propagation of the Gospel, which served as religious couriers of empire among non-white peoples encountered by the British in their outward expansion. ${ }^{75}$ This is ironic in light of Andrew Porter's argument that missionaries typically felt "anti-imperialist" and that their relationship to empire-building was "ambiguous at best." ${ }^{, 76}$ In the British Protestant context, ambiguity toward the nature of imperialism solidified into something much more utilitarian than grand visions of a global polity: empire, through the means of "exploration, commerce, science, individual Christians, [and the] new missionary societies" was but a means to a proselytizing end. ${ }^{77}$ Nonetheless, this means carried with it one of the most distinct elements of British identity. Taking into consideration the lack of any real uniformity of British Protestant belief in the eighteenth century, it is important to note what British missionaries were not exporting to new lands: a unified faith on a grand scale, supported by the home government. That was a job for the Catholic French and Spanish, whose efforts at mass conversion were to be combated by Protestant preaching. $^{78}$

\footnotetext{
${ }^{75}$ Strong, Anglicanism and the British Empire, 32.

${ }^{76}$ Andrew Porter, Religion versus Empire? British Protestant Missionaries and Overseas Expansion, 17001914 (New York: Manchester University Press, 2004), 13.

${ }^{77}$ Porter, Religion versus Empire, 61.

${ }^{78}$ Carla Gardina Pestana, "Religion," in The British Atlantic World, 1500-1800, ed. David Armitage and Michael Braddick (New York: Palgrave Macmillan, 2002), 78-79.
} 
The symbiotic relationship of religion and empire may have been a general rule, but it was certainly not without exceptions. Writing on the years immediately preceding the war in the American colonies, P.J. Marshall provides a clear illustration of the utilitarian nature of imperialism in the context of religion. He argues that "on the eve of the Revolution...the Church of England in America was in essence no more than a denomination in competition with other denominations. ${ }^{83}$ Further, Marshall points out that American Anglicans were by no means uniformly supportive of British imperial policies, as "a large segment of the revolutionary leadership was Anglican," and "throughout the colonies as a whole only about a quarter of the clergy emigrated." ${ }^{84} \mathrm{Carla}$ Pestana reinforces Marshall's disconnection of religion and alliance with the British government by pointing out that Anglicans in one American colony may have chosen loyalty to the crown while Anglicans the next colony over chose to align themselves with the "patriots" or "rebels.". 85

A lack of imperial authority radically changed the status of Anglican faith in the troublesome North American colonies. The revolution proved that while religion and imperial power often went hand in hand it was possible for that religion to remain in some form with the disappearance of imperial power. According to Marshall, "American Anglicans experienced the most complete relinquishment of authority and drying up of support...many churches had been closed and their congregations dispersed" after the end of the American War for Independence ${ }^{86} \mathrm{He}$ reconciles the disappearance of British imperial authority with the continuation of Anglican faith by outlining the rebuilding of

\footnotetext{
${ }^{83}$ P.J. Marshall, "Transatlantic Protestantism and American Independence," The Journal of Imperial and Commonwealth History 36 (2008): 346.

${ }^{84}$ Marshall, "Transatlantic Protestantism," 350.

${ }^{85}$ Pestana, "Religion," 86.

${ }^{86}$ Marshall, "Transatlantic Protestantism," 352.
} 
the Anglican Church under a structure that would later come to be known as the Episcopal Church. While the Anglican Church could no longer be a part of American political life, the theology of the church and its body of believers remained. After being told by English Anglican bishops that they would not consecrate him without the consent of the British government, Samuel Seabury sought (and received) episcopal consecration from Scottish Anglican bishops in defiance of their southern counterparts. ${ }^{87}$ In order to prevent this from happening again, the English bishops gave Americans permission to be consecrated by the English without requiring any oath of loyalty to the British crown. ${ }^{88}$ Thus, much Anglican theology lived on in the nascent United States without owing any political allegiance to a British monarch. This rather limited example of Marshall's argument on the government-religion relationship shows that empire had served as the medium for transmitting religion. Once that empire receded, however, it did not take religion back with it. A vicious war for independence would serve as the powerful solvent to eliminate the connection between one strand of Christian faith and British imperial might.

\section{"Rule, Britannia! Britannia, rule the waves!": The British Navy and the Sea ${ }^{89}$}

Another fundamental aspect of British identity was naval power. Land-based military power served less purpose than naval force for the British; for this reason and others (most importantly trade), naval power was one of the cornerstones of British imperialism in the eighteenth century.

\footnotetext{
${ }^{87}$ Marshall, "Transatlantic Protestantism," 353.

${ }^{88}$ Marshall, "Transatlantic Protestantism," 353.

${ }^{89}$ Part of a verse from James Thomson's "Rule, Britannia," which originally appeared in "Alfred," a masque produced by Thomson and Thomas Arne.
} 
This combat-oriented aspect of British sea power was highly important to a British sense of security. In the Oxford History of the British Empire, N.A.M Rodger points out that in the eighteenth century the British navy served to protect Britons from imperial enemies. The largest, and most potentially lethal, example of these imperial enemies lay directly across the English Channel: "[the navy] did not need to exaggerate the fears of people living a day's sail from the largest army in Christendom, to say nothing of a legitimate pretender to the throne and the horrors of Catholicism." Fortunately, a powerful ocean-based defensive system sat between the British and the French.

In retrospect, historians are able to confidently assert the navy's effectiveness in protecting British interests (and British territory) from French incursion; however, whether Britons at the time were aware of the level of the navy's proficiency is not entirely clear. While it is not the purpose of this thesis to discuss whether those frightened Britons were aware of a distinct lack of professionalism in the protective British navy, as elucidated by Rodger:. in the eighteenth century, the navy had no strategy by which it operated, other offensive or defensive. Rodger further clarifies that this does not indicate that an overall plan of action was simply not codified in a coherent document: when it came to "maritime strategy...eighteenth-century British statesmen and admirals knew neither the word nor the thing."91

Judging by this apparent strategic ignorance, during the eighteenth century the British navy operated as a relatively blunt instrument that simply reacted to various threats as they appeared. Images of a well-organized naval fighting force arrayed in

\footnotetext{
${ }^{90}$ N.A.M Rodger, "Sea-Power and Empire, 1688-1793," in The Oxford History of the British Empire, vol. II, ed. P. J. Marshall (New York: Oxford University Press, 1998), 169.

${ }^{91}$ Rodger, "Sea-Power and Empire," 171.
} 
military splendor, evenly spaced down the length and across the breadth of the English Channel as an impenetrable barrier to stop Catholic France, may well have been illfounded and utterly fantastic. Naval commanders may have been in possession of some combat experience, some knowledge of maritime fighting technique, and some level of formal training, but a coherent strategy? Apparently not. When according to Thomson guardian angels sang the imperative strain of British naval dominance, they did not bother to tell naval commanders exactly how to go about ruling the waves. ${ }^{92}$

Surely such an assertion that the British navy in the eighteenth century operated with no discernable strategy bears mitigation by certain factors - after all, one cannot help but be skeptical that an apparently incohesive naval force maintained maritime domination. Donald Graves offers some explanation, indicating that had they been aware of the inner workings of the British navy and political involvement in maritime operations Britons could have rested much more securely than suggested by Rodger. Graves offers as evidence the level of strategic planning that took place between naval and land-based military forces. His detailed account of the siege and conquest of Quebec in 1759 claims that "in June 1759 when the crews of Vice-Admiral Charles Saunders's ships saw the town of Quebec for the first time, the Royal Navy had a workable doctrine for amphibious warfare. ${ }^{, 93}$ Through his exposition of the status of the British navy by the time of the Siege of Quebec, Graves offers a clear response to Rodger: perhaps those statesmen and admirals knew not the words "maritime strategy," but it is clear that they knew the thing (or at least an amphibious version of it). Surely the momentous victory on

\footnotetext{
${ }^{92}$ See "Rule, Britannia," note 89 above.

${ }^{93}$ Donald Graves, “'A perfect good understanding between the Army and the Navy': British Seapower and the Siege of Quebec," in Fighting at Sea: Naval Battles from the Age of Sail and Steam, ed. Douglas M. McLean (Cap-Saint-Ignace, Quebec: Robin Brass Studio, 2008), 5. Emphasis mine.
} 
the Plains of Abraham would have been impossible had an effective naval force not conveyed the British army there in the first place. By focusing closely on productive collaboration between the British army and navy during the eighteenth century, Graves exposes the clear presence of some level of strategy on the part of both services. "Whatif" history is rarely productive, but one can reasonably understand that without that victory North American colonial undertakings would have assumed a drastically different form.

The presence of the navy as a defensive measure extended beyond the capability to fight off European aggressors to physical mastery of the sea. This is especially interesting given the intellectual currents of the eighteenth century, in which a scientific understanding of nature was coming to be valued over previous modes of religiouslybased thought. In the case of the British this understanding of nature was modified and extended by relative mastery over at least one natural force. The ocean provided a platform upon which British trade materially enriched both the homeland and the colonies; at the same time, that platform was used as a foundation upon which defensive measures were constructed. Such an understanding between man and nature did take a decidedly malevolent turn of events from time to time, however, proving that proficient British sailors were not complete masters of the waves.

Writing on the place of shipwreck narratives in the British conscious in the eighteenth and early nineteenth centuries, Margarette Lincoln contends that such narratives maintained wild popularity and were so popular "chiefly because the actual power of the sea was so frequently impressed upon those living at the time. ${ }^{94}$ Lincoln

\footnotetext{
${ }^{94}$ Margarette Lincoln, "Shipwreck Narratives of the Eighteenth and Early Nineteenth Century: Indicators of Culture and Identity," The British Journal for Eighteenth-Century Studies 20 (1997): 158.
} 
cites Dr. John Wilkinson's circa-1750s estimation that on average, 4,200 Britons died at sea annually. Although she also includes the fact that the 1801 census showed the British population to number ten and a half million people, Britons aware of the sea's terrifying power were probably not particularly comforted that the number lost at sea amounted to less than one percent of the total population. The water by which the British archipelago is surrounded was known to have great power over those who dared venture onto it; thus, not only was naval protection from France important, but dominance of a potentially lethal natural element represented a safeguard from a terrifying and painful death. Of course, plenty of Britons never chose or were forced to embark on oceangoing ships. Even with this in mind, it is understandable that the proficiency of the navy on the high seas did represent a remarkable British achievement. Perhaps those who never engaged in maritime travel were given that much more confidence by knowing that should they have to do such a thing, a powerful naval tradition would hopefully keep them safe.

Awareness of the power of the seas played directly into religious faith -that keystone of British identity - for many who feared succumbing to the deep. Lincoln points to the "call[ing] witness to merciful providence - without dwelling overmuch on those who unfortunately perished." ${ }^{95}$ When lives were lost, surviving Britons were reminded why faith in God was so utterly crucial to daily life. ${ }^{96}$ For proof of which faith held the keys to maritime success, devout Britons had only to look to 1588 and the thorough defeat of the Spanish at the hands of the English navy and the ferocity of nature. The defeat of the Armada proved British superiority in two ways: not only did the

\footnotetext{
${ }^{95}$ Lincoin, "Shipwreck Narratives," 158.

${ }^{96}$ Lincoln, "Shipwreck Narratives," 160.
} 
Spanish fail in their naval endeavor against the British, but a Catholic force had miserably failed in the face of Protestant power.

After mentioning the connection between religious faith and naval ability it is only appropriate to spend some time examining James Thomson's 1740 composition "Rule, Britannia," which serves as an example of this belief in divine approval of maritime mastery:

When Britain first, at Heaven's command / Arose from out the azure main; / This was the charter of the land , / And guardian angels sang this strain:/ "Rule, Britannia! rule the waves: / Britons never will be slaves."

Two hundred and seventy years after Thomson's work was penned, no small number of Britons still enthusiastically bellows verse and refrain of "Rule, Britannia" every year as the BBC orchestra performs Thomas Arne's musical accompaniment during the annual Proms. Thomson locates both Britain's origins and continued success in the divine mandate to dominate the seas: God both pulled Britain from the sea and commanded the nation to rule the waves under the influence of no other earthly power.

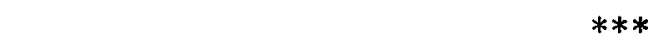

"Britishness," though often vague, difficult to define, and at times intellectually challenging, is nonetheless one of the most important topics to historians of Britain in all its aspects. What is important to bear in mind while examining this fluid and rough-cut identity is that scholars are not the only ones who have felt a need to understand this people and their empire from the outside looking in, either geographically or temporally: those who lived through the empire needed to understand it, and themselves. This chapter has approached only a tiny selection of the issues that defined who the British were in the eighteenth century; however, it is clear that self-identification through the roles of "other," religion, and naval power in British life was a crucial task for the British. These 
three issues were enormous components of the British identity, and by tracking their use, perception, and appropriation, the historian can add even greater detail to the rich portrait of the British and their empire. Britain's image has been substantially clarified in the subsequent centuries of historical work, but narrowly written studies such as those outlined above can make great progress toward bringing that image into greater focus.

\section{III}

\section{Atlantic History}

Atlantic history has become an important field of inquiry, developing from the end of the twentieth century and into the twenty-first. Historians have begun approaching maritime cultures with a new perspective in mind: could it be that the countries that border bodies of water of continental or hemispheric proportions, previously understood according to their political boundaries, are better studied in a different manner? The purpose of this chapter is to examine the historiography of Atlantic history so that this perspective can later be applied in a specifically British context.

One of the founders of Atlantic history is Bernard Bailyn. Bailyn laid out what he called very simply "the idea of Atlantic history" in a 1996 Itinerario article later adapted for publication as the monograph Atlantic History: Concepts and Contours. Atlantic History established the basic landscape of the Atlantic world: the Atlantic Ocean formed something of an "inland sea" of Western civilization, akin to Fernand Braudel's idea of oceanic connections found in The Mediterranean and the Mediterranean World ${ }^{97}$ Peter

\footnotetext{
${ }^{97}$ Bernard Bailyn, Atlantic History: Concepts and Contours (Cambridge, MA: Harvard University Press, 2005), 12.
} 
Coclanis applied the term "Bailynesque" to this interpretation of Atlantic history, defining the slightly tongue-in-cheek neologism as "a complex and elaborate historical design of intersecting and in some cases intertwined parts...the design brilliantly combines social, economic, and intellectual history, and occurs in the historical scholarship on Europe and America during the early modern period and the early, modern period." 98

Bailyn's earlier The Peopling of British North America actually utilized this Atlantic framework by reorienting the historical perspective on North America. Having constructed the book around four propositions to which are attached detailed explanations, Bailyn's fourth proposition reads

American culture in this early period becomes most fully comprehensible when seen as the exotic far western periphery, a marchland, of the metropolitan European culture system. ${ }^{99}$

This construct goes beyond acknowledging the European roots of early American culture; it perceives a connection between the two sides of the Atlantic much greater than one side serving as contributor and the other as recipient of culture and history. In a manner that will be detailed below, Bailyn's fourth proposition hints at the powerful connection between homeland and transatlantic activity around which Atlantic history is largely built.

David Armitage and Michael Braddick's 2002 edited volume The British Atlantic World: 1500-1800 added considerably to the "Bailynesque" interpretation of Atlantic history. Armitage's opening essay defines three aspects of Atlantic history, breaking the overall framework down into circum-, trans-, and cis-Atlantic modes of thought. Circum-

\footnotetext{
${ }^{98}$ Peter A. Coclanis, "Drang Nach Osten: Bernard Bailyn, the World-Island, and the Idea of Atlantic History," Journal of World History 13 (2002): 169.

${ }_{99}^{99}$ Bernard Bailyn, The Peopling of British North America (New York: Knopf, 1986), 112.
} 
Atlantic history focuses very narrowly on the Atlantic Ocean as "a particular zone of exchange and interchange, circulation and transmission." ${ }^{100}$ This seems rather obvious, and Armitage himself admits that this is probably the most readily apparent interpretation. However, he also specifies that this history "is...the history of the ocean as an arena distinct from any of the particular, narrower, oceanic zones that comprise it." Whereas the ocean may otherwise play the role of transmitting medium, circum-Atlantic history as interpretative framework elevates the ocean as the object of study.

Those countries relegated to supporting roles in circum-Atlantic history regain their status through trans-Atlantic history. This method lays out the histories of the places constituting the Atlantic world side-by-side in order to understand differences and similarities. ${ }^{102}$ If one thinks of circum-Atlantic history as focusing on the center of the Atlantic world, then trans-Atlantic history inverts that perspective and throws the bordering countries into brighter light.

Cis-Atlantic history tightens the focus of trans-Atlantic history, narrowly examining a given subsection of the geographic "frame" surrounding the ocean, exploring "unique locations within an Atlantic world and seek[ing] to define that uniqueness as the result of the interaction between local particularity and a wide web of connections and comparisons." ${ }^{103}$ This web is the defining aspect of cis-Atlantic history: without distinctly Atlantic connections, cis-Atlantic history is not possible.

Armitage's suggestion of these three branches of Atlantic history is not the end of the story, however - that would imply that there are three methods of understanding one

\footnotetext{
${ }^{100}$ David Armitage, "Three Concepts of Atlantic History," in The British Atlantic World. 1500-1800, ed. David Armitage and Michael Braddick (New York: Palgrave Macmillan, 2002), 16.

${ }^{101}$ Armitage, "Three Concepts of Atlantic History," 16.

${ }^{102}$ Armitage, "Three Concepts of Atlantic History," 18.

${ }^{103}$ Armitage, "Three Concepts of Atlantic History," 21.
} 
particular entity. From a conceptual standpoint the history of Atlantically-oriented people and institutions illustrates a greatly divided body of water. Alison Games complicates the Atlantic story by writing that "the Atlantic did not form a monolithic region. The Atlantic world may be a coherent unit of analysis, but that does not mean that it was singular, uniform, or harmonious." 104 This is the thrust of differences between "national Atlantics," as it were - the British Atlantic was not the same as the French, Spanish, or Portuguese Atlantic. What the Atlantic actually meant to each of these groups was often different from what the ocean meant to the next national grouping.

As recently as 2009, Kenneth Andrien described the varied nature of the Spanish Atlantic world: differences existed not only between the Iberian motherland and transatlantic holdings but within those colonial areas, too. Andrien forwards Atlantic history as a frame of reference within the Spanish system, which included “differences...between the densely populated central regions and the more sparsely settled frontier zones [Andrien specifically cites Florida, Louisiana, New Mexico, and Paraguay] - where Spanish rule was more insecure as various indigenous groups challenged Spain's control, along with competing European powers." ${ }^{105}$ Different areas placed different demands on Spanish officials. Although this may seem obvious on the surface, it carries important implications for conceiving of Atlantic history. True enough, much of Western Europe in the eighteenth century was intimately involved in Atlantic dealings; however, it would be inaccurate to simply dump everything into the same category of "Atlantic activity." Trade, the spread of religion, direct extension of

\footnotetext{
${ }^{104}$ Alison Games, "Introduction, Definitions, and Historiography: What is Atlantic History?" Magazine of History 18 (2004): 3.

${ }^{105}$ Kenneth Andrien, "The Spanish Atlantic System," in Atlantic History: A Critical Appraisal, ed. Jack P. Greene and Philip D. Morgan (New York: Oxford University Press, 2009), 72.
} 
governmental control, smuggling, piracy, and governmentally-sanctioned plundering - all of these things took place on the Atlantic, and everyone on the sea was involved. This lack of uniformity introduces a key question: if, as Games proposes, the Atlantic did not provide a uniform world - if it is only a convenient unit of analysis - then how can Armitage's concept of circum-Atlantic history hold up? After all, Armitage himself admits that "there were, of course, many smaller zones of interchange around the fringes of the Atlantic basin, whether in West Africa, in western Europe, or around the Caribbean, which possessed similar characteristics." 106 The answer lies in a modification of both Games's and Armitage's definitions of Atlantic history.

The unavoidable terms of geography force the argument of the Atlantic as divided ocean to give considerable ground - after all, the Atlantic is a singular body of water. Even if Atlantic-bound sailors and statesmen in the eighteenth century theoretically divided the ocean into multiple zones, the simple fact remains that it is but one ocean, and the interaction between Europeans upon that body of water unites their activities into a single analytical framework. This is how circum-Atlantic history can be used to explain the events and trends which played out over the course of the eighteenth century on the Atlantic.

It is true enough that the various players on the Atlantic stage were engaged in a wide variety of activities. Games advances this as the precise reason that the Atlantic cannot be understood as a whole; Armitage attempts to bring this fact into his own framework with the inclusion of trans- and cis-Atlantic histories. However, setting Armitage's two branches of Atlantic history up as conceptual equals is an attempt to have one's cake and eat it, too. With this in mind perhaps the concepts of trans- and cis-

\footnotetext{
${ }^{106}$ Armitage, "Three Concepts of Atlantic History," 16.
} 
Atlantic history should be relegated to subsets of circum-Atlantic history, in a more hierarchical structure. This allows the historian to resolve the conflict between the ideas of one Atlantic world and multiple, overlapping Atlantic worlds.

There is an additional consideration to make: if one can agree that the Atlantic world is comprehensible as a unitary structure, then what are the boundaries of that structure? In other words - what was the Atlantic? Not only do fluid boundaries (no pun intended) complicate the question, but the ease of nautical travel between oceans throws a strictly Atlantic approach into question. Paul Mapp writes that

proponents of Atlantic history can simultaneously acknowledge that characteristics of it extended beyond the Atlantic basin and argue that what defines the Atlantic world is not just the presence of a process such as European expansion but the intensity of connection among the peoples of four continents. $^{107}$

This is a particularly engaging critique of Atlantic history as a conceptual paradigm and limits its usefulness as a thematic framework. If one considers some general "categories" of Atlantic activity, it becomes clear that the Atlantic was merely incidental. The spread of religion, trade, exploration, and warfare all took place in non-Atlantic settings as well. Thus one is nudged toward concluding that perhaps the Atlantic is useful only as a geographic framework. The boundaries - both conceptual and geographic - are too loose to block off the Atlantic from the rest of the globe's nautical routes. Historians who speak of Atlantic history must then do so in terms of events and trends which took place in a specifically Atlantic context. Atlantic history takes the form of a geographic area of study.

Another questionable component of an Atlantic approach, according to Peter Coclanis, is assigning too much importance to developments taking place in the West

\footnotetext{
${ }^{107}$ Paul W. Mapp, "Atlantic History from Imperial, Continental, and Pacific Perspectives," The William and Mary Quarterly 63 (2006): 721. Emphasis mine.
} 
under the auspices of West European powers - the Atlantic and "New World" events that shaped the histories of Britain, France, the Netherlands, Spain, and Portugal. Things happening on the other side of the world had highly important roles to play in the Atlantic itself. In a passage worth quoting at length, Coclanis questions the Atlantic perspective by saying

For example it defies logic to proceed under the assumption that the Atlantic world was a discrete economic unit when roughly 75 percent of one of its most important (and certainly celebrated) economic resources, American silver, ended up in China during the early modern period and when the Spanish real functioned as the international trading currency over much of Asia. Moreover the African slave trade ran largely on textiles - long cloths, Guinea cloths, allijars, salemporis, etc. - from India and cowrie shells from the Maldives. And speaking of Indian textiles, how does a dyed-in-the-wool Atlanticist explain the appeal of Indian calicoes that dominated the English textiles market as well as the appeal of Indian Guinea cloth in the West Indies and British North America in the late seventeenth and early eighteenth centuries? ${ }^{108}$

This reinforces the interpretation of Atlantic history as a strictly geographic unit of reference. Coclanis uses the issue of trade as an example of extra-Atlantic movement; however, similar themes can be traced in the areas of religion, government, and military expansion.

This raises a significant question in light of the Games's claim that Atlantic history must shed any idea of political boundaries, in historiography and even in the structuring of history faculties. ${ }^{109}$ But if one assumes this approach - one "unfettered by state borders" - then one must logically push the argument through to its conclusion and question whether or not it is reasonable to construct the Atlantic Ocean as a more significant unit of analysis. ${ }^{110}$ By expanding this argument to an

\footnotetext{
${ }^{108}$ Peter Coclanis, "Atlantic World or Atlantic/World?" The William and Mary Quarterly 63 (2006): 731. ${ }^{109}$ Alison Games, "Atlantic History: Definitions, Challenges, and Opportunities," The American Historical Review 111 (2006): 749.

${ }^{110}$ Games, "Atlantic History: Definitions, Challenges, and Opportunities," 743.
} 
extreme, one could understandably wonder whether Atlantic history takes on the appearance - if not the outright identity - of yet another form of "area studies," one bounded by rather arbitrary borders between bodies of water.

Extending the argument to the point that Atlantic history becomes a form of area studies is not a club with which to beat Atlanticists. Acknowledging that Atlantic history is subject to arbitrary geographical boundaries and must remain constrained physically rather than thematically allows the historian to soundly dispute the assertion that Atlantic history is history operating outside the constrictions of political boundaries. Certainly, the historian can make the case that the political boundaries of modern countries are often in flux; this was certainly so during the eighteenth century. However, these boundaries are still useful containers within which one is able to think: if nothing else, they operate as an excellent organizing framework within which one can clearly demarcate specific groups of people who operated within the Atlantic.

David Armitage and Bernard Bailyn have provided another answer to such a conundrum: if Atlantic history operates above and beyond national boundaries, then what good are they in the first place? Armitage's cis-Atlantic history greatly modifies the "Atlantic as one world" argument. If cis-Atlantic history provides the framework for understanding the uniqueness of particular localities involved in Atlantic activity, then those unique iterations all contribute to the harlequin nature of Atlantic history. In turn, this history cannot be understood without the borders of particular countries - to attempt to do so is to begin to ignore Armitage's insightful construction of cisAtlanticism. One may be tempted to claim that commonality of purpose - trade, military expansion, slavery, evangelism - eliminates the need for individual, national approaches 
to Atlantic history. However, this is far too close to a thematic interpretation of Atlanticism, an interpretation that simply does not work - themes did not make the Atlantic unique.

Thankfully, one can return to Bailyn for something of a unifying thread to pull all of this together. Bailyn shows that perhaps Armitage's cis-Atlanticism and Games's noborders theory can play well together: "Atlantic history is not additive; it is more than the sum of its parts." 111 This description combines the most useful components of Armitage and Games. Each of the "parts," as it were, of Atlantic history contributes uniquely to that history; in total, they create something much larger that in turn assumes its own form. In this manner, the historian understands that all of those unique people and places that participated in the "Atlantic world" worked together in a zone of activity that scholars can now call, in a willing anachronism, the Atlantic world.

"1' Bailyn, Atlantic History, 60. 


\section{CHAPTER TWO: ONE OF THE ATLANTICS - A BRITISH PERSPECTIVE}

Several national groups used the Atlantic in the period of aggressive European expansion across the ocean, from approximately 1500 to 1800 . The Atlantic played an important role for the British, as prior to the nineteenth century most British imperial possessions were confined to trans-Atlantic areas. The Atlantic itself was the medium through which the British became imperial contenders with both the French and the Spanish. With this in mind it is worthwhile to spend some time exploring the manner in which Britain fit into the eighteenth century Atlantic world and situating the British within the Atlantic system.

This chapter employs David Armitage's tripartite approach to Atlantic history circum-, trans-, and cis-Atlantic history - to illustrate the specifically British iteration of Atlanticism in the eighteenth century. This also implies a challenge to Alison Games's claim that Atlantic history eschews national histories, as Chapter 1 contends that national histories are important assets for the Atlanticist. It would also be useful to place some specific markers of British identity discussed in Chapter 1 within a specifically Atlantic context; so as to avoid a rehearsal of all those markers, this chapter is limited to the significance of the ocean to British identity and British Protestantism. Considering the importance of the Atlantic to the British in the eighteenth century, situating those themes discussed above in an Atlantic context is a useful exercise (particularly as it can illustrate both the boundaries of Atlantic interpretation and the shortcomings of not utilizing the Atlantic perspective). 
If cis-Atlantic history is the history of places made unique by their connection to the Atlantic, then one can safely say that the British in the eighteenth century contributed to the cis-Atlantic history of several different geographical locations. ${ }^{2}$ First and foremost among these places was Britain itself. The possession of an Atlantic empire had an enormous impact on the British home islands, predominantly of an economic nature. Jacob Price's analysis of the eighteenth-century imperial economy illustrates that the overseas territories held (or frequently visited) by the British via the Atlantic served as sources of great wealth, either through the re-export market or by making products for British consumption. His analysis of eighteenth century trade reveals that the most important of these products that found a growing home in the British archipelagic market was sugar: Britons satisfied their craving for the sweet substance by consuming sugar produced in the West Indian plantations. ${ }^{3}$ The West Indies alone did not satisfy all of Britain's material desires: once it was discovered that indigo could be grown in the North American colonies, those territories became a vital source of the plant to supply the dye market and provided an alternative to purchasing indigo from the French. ${ }^{4}$ Finally, North American colonial holdings served as the source of "raw materials for British industries:

\footnotetext{
' In his essay in The British Atlantic World, Armitage offers these three conceptual frameworks in an order reversed from that presented here. I have intentionally reversed his original order so that circum-Atlantic history appears last in this thesis, for reasons that will become apparent to the reader below.

${ }^{3}$ Jacob M. Price, "The Imperial Economy," in The Oxford History of the British Empire: The Eighteenth Century, vol. II, ed. P J. Marshall (New York: Oxford University Press, 1998), 81. Price points out that between 1770 and 1779 per capita consumption of sugar was around 11 pounds, as opposed to 2 for the French.

"Price, "The Imperial Economy," 82. Price explains that the British previously needed to purchase indigo from the French, as prior to the outbreak of war midcentury the French provided an indigo market as they still grew it in their Caribbean holdings - sugar had eliminated the production of indigo on British Indies islands.
} 
whale-oil, skins and furs, and shipbuilding supplies," in addition to rice for the European re-export market. ${ }^{5}$

The production of all these things required intense labor. The voluntary labor demands of British Atlantic territories had a transformative effect on British home population, as elucidated by Nuala Zahediah's essay in Armitage and Braddick's British Atlantic World: as the British population grew rapidly in the eighteenth century, American production capacity was fueled partially by an emigrant labor force, thus relieving the burden of more and more people in Britain. ${ }^{6}$ In this way it was not only material imports that changed Britain - the export of people also contributed greatly to the country's transformation in the eighteenth century. Bernard Bailyn's The Peopling of British North America offers another explanation for the outflow of people during the eighteenth century (and to some extent the seventeenth): land speculation. ${ }^{7}$ Citing the "millions of open acres east of the Mississippi," Bailyn illustrates the enticements dangling before the eyes of "susceptible populations" in Europe, who could be tempted to cross the Atlantic and leave behind the poor conditions in which they lived. ${ }^{8}$

Zahedieh neatly encapsulates the greatest impact that Atlantic commercial activity had on Britain during the eighteenth century by saying

Surplus population was transplanted out of a 'tight place' to new lands in America and set to work producing valuable cash commodities. The colonies provided Britain with substitutes for a wide range of imports and an overplus for sale in European markets. As American production increased and real prices fell, luxuries such as sugar and tobacco became available to all, fundamentally

\footnotetext{
${ }^{5}$ Price, "The Imperial Economy," 83-86.

${ }^{6}$ Nuala Zahedieh, "Economy," in The British Atlantic World, 1500-1800, ed. David Armitage and Michael Braddick (New York: Palgrave Macmillan, 2002), 61.

${ }^{7}$ Bernard Bailyn, The Peopling of British North America (New York: Alfred A. Knopf, Inc., 1986), 20.

${ }^{8}$ Bailyn, The Peopling of British North America, 38. Bailyn specifically cites the case of Scottish weavers in 1773, who threatened to leave for America if their employers did not offer higher wages. The chief judge of the case brought against the laborers was relieved that, after imposing light sentences, "all thoughts of going over to America are for the present laid aside."
} 
changing British consumption patterns in ways which helped to stretch limited resources. The colonies also provided a growing market for British manufactured goods, encouraging product diversification and improved organization in industry to reduce unit costs. ${ }^{9}$

Transatlantic imperial holdings provided cheap goods to be consumed by Britons; the demand for labor in those places relieved the pressures of population. This relief must be borne in mind simultaneously with the type of situation discussed by Bailyn - not every case of emigration was desirable, and leaving Britain for the New World could also represent escaping what were perceived as poor conditions for a better life abroad, sometimes to the detriment of others. The new American and West Indian industries needed labor, true enough; however, the home industries needed labor, too, and in those areas which did not suffer from the problems of a high population the exportation of people could represent a threat to local business.

The cis-Atlantic implications of Britain's Atlantic empire were not confined solely to economics. Robert Olwell's "Seeds of Empire" describes the effect of transatlantic possessions on Britain's imperial self-conception and efforts at comparison with other eighteenth-century empires. The Treaty of Paris stipulated the cession of Florida to the British by the Spanish; once a British government presence was established, botanical samples were sent by governor Alexander Grant to amateur botanist Lord Bute, who had pulled the appropriate strings to land Grant the governor's job. ${ }^{10}$ These seeds were tokens of British ownership of the new and exotic land: once

\footnotetext{
${ }^{9}$ Zahediah, "Economy," 67.

${ }^{10}$ Carole Shammas, introduction to The Creation of the British Atlantic World, ed. Elizabeth Mancke and Carol Shammas (Baltimore: The Johns Hopkins University Press, 2005), 14-15. Shammas's introduction indicates that this was a move made out of genuine gratitude; it is not unreasonable to assume Grant was willing to keep in the game of patronage, as well. Grant was well aware of Bute's interest in exotic flora, and would have known that sending the Prime Minister Florida seeds would keep him high on the earl's list of beneficiaries.
} 
Florida plants could be grown at Kew, Britons would be able to see one example of the vast range of territory held by Britain.

But what exactly did these seeds symbolize? Why did it really matter that the British owned Florida? A great deal of other territory had been gained as a result of the Treaty of Paris. Uniquely, Florida offered a landscape not found in the other major colonial gain (northern North America) - a somewhat tropical and relatively exotic setting. And not only was the landscape unique and full of exciting flora never before seen, but it was now under new ownership. Olwell describes why British possession would prove more advantageous to Florida than Spanish rule: "the answer lay in a crude, but popular stereotype: "the Spanish are too lazy." "11 Florida could flourish under British control; the Black Legend apparently extended beyond torture, religious intolerance, and murder to insufficient stewardship of lush greenery.

This admittedly limited description of botanical and governmental supremacy is nonetheless indicative of the changes wrought on Britain directly by its Atlantic connections. Growing Florida plants in a Kew greenhouse was an important symbol of imperial power, especially with the added implication of supremacy over Spain as an imperial ruler. This was an element of confidence uniquely provided by Britain's increasingly important Atlantic connections in the eighteenth century.

These examples serve as excellent representations of David Armitage's cisAtlantic approach to British history. The export of British colonial production across the ocean had an enormous economic impact back home; at the same time, the uniqueness of

\footnotetext{
"Robert Olwell, "Seeds of Empire: Florida, Kew, and the British Imperial Meridian in the 1760s," in The Creation of the British Atlantic World, ed. Elizabeth Mancke and Carole Shammas (Baltimore: The Johns Hopkins University Press, 2005), 273.
} 
those holdings added to British self-conceptions and feelings of superiority over imperial rivals.

Armitage's second interpretation of Atlantic history, that of trans-Atlanticism, also bears discussion here. Armitage points out that this is often accomplished along a north-south axis, as the major players in the Atlantic and their empires were geographically situated in a north-south orientation. ${ }^{12}$ An important distinction that should be made between cis- and trans-Atlantic history is the geographical demands of trans-Atlanticism. While one can certainly engage in cis-Atlantic studies of European locations - specific ports, cities, regions, and so on - on those locations' own merit, it is difficult to understand the trans-Atlantic history of European nations without focusing almost exclusively on the territorial possessions of the New World. Thus the only viable objects of comparison are New World holdings.

A concept that can shed light on the trans-Atlantic perspective is one of the most powerful themes in many historical discussions: religion. As discussed above, Protestantism was one of the key markers of British identity in the eighteenth century; to a certain extent, this was also true in imperial expansion and the interactions maintained with natives. Although speaking within the general framework of the seventeenth century, the commentary offered by Carla Pestana on the comparative approaches to missionary activity by the British, French, and Spanish is indicative of the general religious mindset of the British into the eighteenth century. The great religious divide between Britain and France and Spain was, of course, along Protestant and Catholic lines.

\footnotetext{
${ }^{12}$ The imperial possessions of these major players - Britain, France, and Spain - were, geographically speaking, also arranged on a roughly north-south axis (northern North America for France, eastern North America for Britain, Central and South America for Spain, with a small mixture in the Caribbean).
} 
This division is further complicated by the respective approaches to proselytizing in the New World.

British Protestant ministers looked down upon Catholic priests, writes Pestana, as they "'sprinkled' natives and considered them Christians." ${ }^{14}$ From the Protestant perspective, Catholic conversions stopped there. Pestana reveals that "Protestant ministers dismissed the far more successful missionary efforts of Catholics...because these conversions were not accompanied by a complete re-education effort." Catholic priests were willing to retain some elements of native religion and integrate them into the newly-arrived Christianity, whereas Protestant missionaries desired the total elimination of indigenous religious belief. ${ }^{15}$ This either-or dichotomy assumed by the British extended beyond the realm of religious faith, however, and one can see the differences between British and French/Spanish religious conversion attempts as reflections of larger psychologies of inclusion and exclusion.

Speaking of eighteenth-century conditions established by the actions of British and Spanish colonizers in the previous two centuries, J. H. Elliott draws a simple line between the activity of the Spanish in Central and South America and the British in North America: "The friars and the Jesuits were the advance agents of a Spanish frontier policy that sought to be a policy of inclusion, absorbing and assimilating the indigenous population, in contrast to the frontier policy of exclusion that had become the norm among the British colonies to the north." ${ }^{16}$ Kenneth Andrien points out that Spanish

\footnotetext{
${ }^{14}$ Carla Pestana, "Religion," in The British Atlantic World, 1500-1800, ed. David Armitage and Michael Braddick (New York: Palgrave Macmillan, 2002), 79.

${ }^{15}$ Pestana, "Religion," 79. Emphasis mine.

${ }^{16} \mathrm{~J}$. H. Elliott, Empires of the Atlantic World: Britain and Spain in America 1492-1830 (New Haven: Yale University Press, 2006), 269. It is important to note that, even though Elliott specifically mentions Spanish priests as part of this assimilatory policy, this is only indicative of the integration of Catholicism with Spanish governmental activity; while Spanish priests certainly sought the conversion of natives, such
} 
expansion into the territory on the far side of the Atlantic "created a 'New World' that was not entirely European, Native American, or African," through "the importation of African slaves and intermarriage and casual sexual unions between Europeans and the indigenous peoples." 17

Joyce Chaplin cites "the gradual eighteenth-century movement to reject Indian slavery," a question which revolved around the subjecthood status of subordinates: if Indians were enslaved, did that mean they, as a group, were British subjects? And if they were British subjects, what did this entail in terms of their treatment? Those wary of enslaving Indians were thus resolved that the best solution to the problem would be to understand natives as free - thus, a proper sense of difference and separation could be maintained. ${ }^{18}$ Although Chaplin's explication of the circumstances surrounding the Indian non-enslavement movement is not particularly clear on this point, it is reasonable to infer that conceding subjecthood under the British Crown would have required a modicum of decency on the part of slaveholders. However, that would have introduced another conundrum: as Crown subjects, slaves would be due the rights, privileges, and status of any other subject. And so, the movement claimed, there was a great deal of difficulty in justifying Indian slavery in the minds of those who took the time to consider it. As the rest of Chaplin's essay indicates, this certainly did not stop a vast number of Indians from being enslaved by those with no qualms about questions of subjecthood; blacks would receive very little consideration during the eighteenth century in general,

conversion often entailed inclusion within a broader Spanish social structure that comprised much beyond the realm of religion.

${ }^{17}$ Kenneth J. Andrien, "The Spanish Atlantic System," in Atlantic History: A Critical Appraisal, ed. Jack P. Greene and Philip D. Morgan (New York:Oxford University Press, 2009), 55.

${ }^{18}$ Joyce Chaplin, "Enslavement of Indians in Early America," in The Creation of the British Atlantic World, ed. Elizabeth Mancke and Carole Shammas (Baltimore: The Johns Hopkins University Press, 2005), 47. The movement of which I speak here was simply that: one movement among a wider social institution, and native slavery certainly continued alongside the enslavement of blacks. 
until the writings of men like Olaudah Equiano received a wide circulation toward the end of the century.

Refusal to allow Indians subject status also extended into persons of mixed ancestry. Writing in Armitage and Braddick's The British Atlantic World, Chaplin highlights the difference between existence and acknowledgement of miscegenation in a passage worth quoting at length:

It has long been thought that sexual activity across the 'races' was more characteristic of Iberian and French colonies than of English ones. But the 'lack' of mestizos in Anglo-America now seems suspect. Such people indeed existed, but it has taken determined reinterrogation of the historical record to discover them. Their existence shows that, in British America, mixed-race peoples were not absent - official recognition of them was. Whereas the state in Spanish America and in New France was alert to the sexual behaviors of Christians, and to the engendering of people of part-Christian parentage, political and religious officials in the Anglophone colonies took no such interest. Such behaviors were private, albeit illegitimate, and the children who resulted were likewise regarded as illegitimate and beneath public notice. ${ }^{19}$

This is certainly not to suggest that creoles or children of mixed parentage were happily embraced by the Spanish and the French in all situations, especially in terms of leadership. Elliott offers the example of mestizo anger over the apparent preference shown to native Spaniards (peninsulares) in appointments to New World judicial positions in the late eighteenth and early nineteenth centuries. ${ }^{20}$ It seems the Spanish crown was not satisfied with only partially Spanish lineage or birth in the Central and South American colonies, even in the case of those who had been born after the era of Spanish expansion. The fact that non-peninsulare officials were even able to enter into a dialogue with the Spanish crown is telling in itself: North Americans in a similar situation were only rarely accorded a listening ear by British officials. Within the constraints of the

\footnotetext{
${ }^{19}$ Joyce Chaplin, "Race," in The British Atlantic World, 1500-1800, ed. David Armitage and Michael Braddick (New York: Palgrave Macmillan, 2002), 168.

${ }^{20}$ Elliott, Empires of the Atlantic World; see Chapter 12 "A New World in the Making," esp. 376.
} 
very limited examples offered here, one sees that trans-Atlantic history thus offers clear paths of comparison between Atlantic powers during the eighteenth century.

Finally, circum-Atlantic history can be applied fruitfully to understanding the British in the eighteenth century. In cis- and trans-Atlantic history, the ocean is a significant contributor to the histories of other elements, but is not the focus itself. The reverse is true with circum-Atlantic history. When speaking of Armitage's "three branches" approach, Chapter 1 asserted that it may be reasonable for cis- and transAtlantic history to be subsumed within circum-Atlantic history. The elevation of the ocean itself as the object of study with individual elements connected to national histories - people, places, and so on - justifies this hierarchical coordination of the three branches. Without cis- and trans-Atlantic history, circum-Atlantic history could not exist: those two more narrowly-defined fields provide the pieces to the larger puzzle that is circumAtlantic history.

The contributory nature of the relationship between Armitage's fields of Atlantic history is not a simply mathematical formula: Bailyn writes "Atlantic history is not additive; it is more than the sum of its parts. ${ }^{21}$ Therefore, the individual locations around the Atlantic (cis-Atlanticism) and the connections between European countries and New World holdings (trans-Atlanticism) contribute to the ocean as a whole (circumAtlanticism). Armitage himself claims that "national histories of territorial states and empires are only part of this history when an ocean creates long-distance connections between them.,22

\footnotetext{
${ }^{21}$ Bailyn, Atlantic History, 60.

22 Armitage, "Three Concepts of Atlantic History," 18.
} 
One of the many components that make up circum-Atlantic history is the British presence on the ocean during the eighteenth century; in this manner, it is possible to speak of a specifically British circum-Atlantic history. With this in mind one can integrate British identity with the ocean itself and explore the role of the Atlantic in the lives of the British.

The significance of the ocean assumed two main forms for the British: military superiority and an Atlantic trade that enhanced the British economy. In terms of trade, it is impossible to ignore one of the largest elements that fueled this component of British maritime mastery. There were a number of tasks which free, white Britons and colonials simply did not do; into this gap, enslaved Africans and their descendants were involuntarily shoved. ${ }^{24}$ In many ways, slaves were the fuel on which the British oceanic trade was run; they certainly formed the backbone, both figuratively and literally, of British commercial success in the eighteenth century.

The importance of the British Atlantic slave trade is revealed by James Horn and Philip Morgan, who have compiled useful statistics on the transportation of slaves out of Africa and into the Americas from the sixteenth to the nineteenth centuries. During the period 1500 to $1820,3,252,000$ slaves arrived; the narrower period of $1700-1820$ saw $2,876,000$ slaves brought over. ${ }^{25}$ Slave transportation extended beyond economic statistics, affecting international relationships (and thus forming an integral component of eighteenth-century trans-Atlantic history). The British South Sea Company held the

\footnotetext{
${ }^{24}$ Timothy Buckner, "The Slave Trade's Apex in the Eighteenth Century" in The Atlantic World, 14502000, ed. Toyin Falola and Kevin D. Roberts (Bloomington: Indiana University Press, 2008), 103. ${ }^{25}$ James Horn and Philip Morgan, "Settlers and Slaves: European and African Migrations to Early Modern British America" in The Creation of the British Atlantic World, ed. Elizabeth Mancke and Carole Shammas (Baltimore: The Johns Hopkins University Press, 2005), Table 1.1, $21-22$.
} 
Spanish monopoly on slave trading (asiento) in the first half of the eighteenth century; in this way the Spanish themselves contributed to the rise of Britain as an economic powerhouse.

Military prowess on the Atlantic was crucial to British feelings of security and strength. The anti-French component of Britishness extended onto the sea, and naval power played a significant part in proving British superiority over all things French during the eighteenth century. Naval success provides the opportunity to explore the significance of maritime superiority in cis-, trans-, and circum-Atlantic terms. One example will suffice.

The Battle of Quebec was offered earlier as an example of Britain's naval identity; here, it serves to spotlight that naval component on an Atlantic stage. This was a battle during which cis- and trans-Atlantic history played out, as the Atlantic Ocean was crucial to Quebec's significance in the tensions between the British and the French. It was a combination of naval and land-based military strategy that allowed the British to succeed over the French at Quebec in 1759. True enough, the army did the majority of the fighting on the Plains of Abraham; however, that army could not have gotten to the Plains without the support of the navy. That battle also exemplifies a significant element of trans-Atlantic history, as two European powers fought for control of a New World locality: surely two "mother countries" fighting over an American city crucial to both imperial programs provides one of the best examples of the mechanics of the transAtlantic perspective.

It is only fair to admit that all the reasons that the ocean figured so prominently in Britons' minds point to some of the problems of the Atlantic approach, and reinforce 
some of Coclanis's misgivings about elevating Atlanticism to a status beyond its utility. In military, economic, and exploratory terms, British skill in navigation was not limited to the Atlantic during the eighteenth century; Peter Wood specifically cites the historiography of the travels of Sir Francis Drake in the Pacific during the eighteenth century. ${ }^{27}$ As another example, the British presence in India during the eighteenth century would not have existed without significant forays into the Indian Ocean.

Invoking non-Atlantic naval endeavors is certainly not to suggest that they assumed more importance than what occurred in the Atlantic during the eighteenth century; in terms of oceangoing activity, the events contained within the Atlantic world were ultimately the more momentous. However, such an invocation is intended to highlight that the various elements of success enjoyed by the British in the Atlantic namely favorable trade circumstances and military victories - were not unique. They formed part of an overall record of extra-archipelagic expansion achieved through maritime skill. The British presence on the Atlantic yielded great rewards for the home country; however, one must acknowledge that these activities were not unique. Oceangoing trade: occurred outside the Atlantic. Military success, either on the ocean or on land (enabled by naval delivery of troops): also existed outside the Atlantic. Furthermore, while much of the Atlantic was already known to the British by the eighteenth century, the Pacific was still something of an unknown and time and energy were spent in the attempt to understand that body of water - expenditures driven by the naval skill that had tamed the Atlantic. The same elements of Atlantic activity that brought the British so much success during the eighteenth century are the elements which

\footnotetext{
${ }^{27}$ Peter H. Wood, "From Atlantic History to a Continental Approach" in Atlantic History: A Critical Reappraisal, ed. Jack P. Greene and Philip D. Morgan (New York: Oxford University Press, 2009), 287.
} 
point out some of the caveats of utilizing the Atlantic lens too heavily. "The ocean" and the British presence upon it had a large influence on British conceptions of identity. However, "the ocean" was not just Atlantic, and while the Atlantic perspective is useful, it is not all-encompassing or sufficient for a total comprehension of what exactly the British achieved by their naval skill. The Atlantic Ocean did have an enormous transformative effect on Britain in the eighteenth century - cis-Atlanticism writ large onto a national scale - in ways discussed above and far beyond. But it was not the only transformative element of oceangoing activity. Aside from the wind, a number of factors pushed British ships across the Atlantic Ocean; Protestantism was one of the strongest. Religion is thus another theme which bears an Atlantic disussion.

Bernard Bailyn describes one part of Atlantic history as "a vast new marchland of European civilization. ${ }^{, 28}$ Viewing European expansion into the New World as a marchland necessarily implies three things which are rather obvious but worth delineating all the same: a safe, comfortable territory of familiarity; an unknown territory, often directly associated with danger and hostility; and some sort of meeting place, a frontier of human interaction. This frontier of human interaction was one of the main concerns of British Protestantism as it expanded into North America. While Native American religions were certainly a threat, surely rational Anglicanism could easily replace native modes of spirituality. The greater threat - especially in the mid-eighteenth century - was Catholicism, particularly of the French variety. ${ }^{29}$

Pestana's description of Protestant British expansion into North America as taking a specifically anti-Catholic tone provides a connection between the "isolated" and

\footnotetext{
${ }^{28}$ Bailyn, Atlantic History, 62.

${ }^{29}$ Pestana, "Religion," 72.
} 
"Atlantic" approaches to British identity that have thus far formed the heart of this thesis. In his The Peopling of British North America, Bailyn argues that British settlements in North America were "an extension outward and an expansion in scale of domestic mobility in the lands of the immigrants' origins." ${ }^{30}$ Bailyn's thoughts on the domestic mobility of new British settlements could reasonably be adapted to religion as well: in other words, one could argue that British Protestantism in North America was "an extension outward and an expansion in scale" of "homestyle" Protestantism. British Protestants were not satisfied with native religions adapted to accept elements of Protestantism, the method preferred by Catholic missionaries - it was all or nothing. ${ }^{31}$

John Elliott's description of the creation of the "myth of the frontier" softens this all-or-nothing approach by explaining the European-American outlook on natives as somewhat redeemed by their closeness to the land and ability to live harmoniously with the vast American frontier. The Indians were not Protestants, to be sure; however, Elliott points to concessions that perhaps a lack of civilization carried with it a lack of vice. ${ }^{32}$ By the middle of the century, that "myth of the frontier" was coming to look something like

Indians still uncorrupted by the vices that civilization brought in its train, and settlers who were... upright and hard-working farmers, living close to God and nature as they cleared spaces in the forests and met the challenges of the wild. The two races inhabited a bountiful land of rugged beauty, a land whose savagery would in due course be tamed by the honest toil of a people no longer European but 'American,' at one with the American environment they had made their own. ${ }^{33}$

Notice that despite admitting that the Indians of this myth were "still uncorrupted by vices," there is no sense of cooperation, mixing, or symbiosis. The European-American

\footnotetext{
${ }^{30}$ Bailyn, The Peopling of British North America, 20. This forms part of number one of Bailyn's four "propositions" which are the framework of the entire book and an excellent methodology of studying the British intrusion into North America.

${ }^{31}$ Pestana, "Religion," 79.

${ }^{32}$ Elliott, Empires of the Atlantic World, 280.

${ }^{33}$ Elliott, Empires of the Atlantic World, 280.
} 
people would make the land their own in due time; "taming" that land carries with it the unspoken implication that the peoples living in the forests to be cleared and the fields to be farmed according to proven European methods either convert or leave.

Native religions were a lesser threat than something even worse lurking beyond the safety of British territorial lines - French Catholicism. Because of this constant threat, the "Other" as described by Linda Colley provided the necessary components for defining British imperial identity in North America. Fred Anderson cites the dilemma of the Acadians during the mid-eighteenth century, a group used as pawns in the struggle between the British and the French in North America. According to Anderson the situation faced by the Acadians throws into relief the essential components of British imperial identity: "willingness to affirm allegiance to the king of England, adherence to some form of Protestantism, anti-Catholicism, and Francophobia.. ${ }^{34}$ This continued beyond the Peace of 1763, as Pestana highlights the advancement of religious liberty in the British North American colonies over that of Britain itself despite "the continued forced of anti-Catholicism." ${ }^{35}$ British North America may have been approaching a greater embrace of plurality than the home islands, but it was not yet prepared to embrace the old enemy, those superstitious papists.

Anderson's definition of what it took to be a part of the British Empire in North America in the middle eighteenth century is a useful example of the intersection between the "isolated" approach to British identity taken in Chapter 1 and the Atlantic approach taken here. This is Colley's "Otherness" writ large, on a scale that crossed the Atlantic. This is Bailyn's "extension outward and expansion in scale," in terms of religion, of

\footnotetext{
${ }^{34}$ Fred Anderson, The War that Made America: A Short History of the French and Indian War (New York: Penguin, 2006), 87.

${ }^{35}$ Pestana, "Religion," 84.
} 
British negative self-definition. Thus, understanding British imperial identity in North America during the eighteenth century - or, at least prior to British victory in the Seven Years' War - requires a trans-Atlantic perspective, the extension of comparisons between "home" cultures to their holdings across the Atlantic.

One limitation of an Atlantic approach becomes apparent when thinking about British Protestantism as it expanded across the ocean. Armitage's definition of transAtlanticism allows us to properly understand the relationship between home and North American British Protestantism, a relationship characterized by the extension and magnification of Protestant identity vis-à-vis French Catholicism. But that extension requires a solid origin, which lies with the concept of "Other" originally felt at home on the British Isles against the old continental foe across the Channel. An analysis of "home island" British antipathy toward the French, and the self-definition of the British as nonFrench, can be carried out in complete isolation from the Atlantic; an Atlantic perspective is not crucial to this aspect of British identity in the eighteenth century. It is when viewing North American Protestantism as an extension of that faith found on the eastern side of the Atlantic that it is necessary to utilize the tools of the Atlanticist and adopt a comparative approach in understanding the tensions that created British North America.

This chapter has featured a variety of examples of the benefits and drawbacks of the Atlantic perspective; it would be appropriate to close with a brief recapitulation of those elements and some general commentary.

An Atlantic perspective is useful and robust when studying the British and their extra-archipelagic activity in the eighteenth century; however, it is not the ultimate 
methodology and is but one of several frameworks which one must employ to fully understand the eighteenth-century British. It should be clear by now that the author places great value in David Armitage's tripartite approach to Atlantic history, even with some modifications related to its structure; in any case, the three "branches" of Atlantic history that Armitage posits are limited in a way that makes analysis much easier. The examples from this chapter illustrate how circum-, cis-, and trans-Atlantic history all bear clear manifestations in the activity of the British and their imperial undertakings during the eighteenth century. The advantages of the Atlantic approach are apparent when one invokes Armitage's cis-Atlantic history, the framework which argues that specific locations are impacted by their connection to the Atlantic Ocean. One can safely view Britain itself as one of those specific locations - a very large one, but on a larger scale it is specific nonetheless. Within a cis-Atlantic paradigm very little effort is required to see the effect that Britain's Atlantic activity had on the home country: massively favorable economic results, enormous territorial gains, and changes in religious outlook. While an Atlantic perspective is not to be overstated, it is necessary and helpful.

It is unreasonable, however, to assign too great a sense of exceptionalism to the Atlantic achievements of the British in that century. Certainly the British presence in the Atlantic was important to the creation of new societies (and to some extent the recreation of European societies) in the New World. However, the elements that led to British success in the Atlantic were not employed only in that somewhat arbitrarily constrained body of water. British endeavors in India and the Pacific in general bear the truth of that. This is where one ultimately sees the value of Atlantic history: a methodology for understanding a geographic construct within which certain themes were played out - 
themes and trends which extended beyond the Atlantic. Within this zone of activity, and in terms of the people and events that moved into and out of that zone, Atlantic history is vital. On the other hand, Atlantic history can very easily become global history and so very specific boundaries must be established.

This caveat points to a larger question that the historian of any Atlanticallyconnected topic must consider: how useful is the Atlantic perspective to a given moment of inquiry? In other words, should Atlanticism take the form of a crucial building block of any subject related to the Atlantic Ocean or that of a helpful but not necessarily fundamental aid? This chapter has shown that it is tempting to establish connections of Atlantic history to a number of events, concepts, and people that may or may not be good candidates for such association; the ultimate conclusion was that Atlantic events are important for their contributory roles in building the histories of those involved, but the Atlantic perspective should not be privileged above all others - this is an unnecessary risk that may cause the historian to lose sight of a more narrowly-defined target.

It is significant that no small amount of the discussion on Atlantic history above has focused on the events happening outside the political boundaries of Britain and its eighteenth century counterpart states - the ocean itself, North America, the Caribbean, and Africa were all places that held great significance in the eighteenth century for Britain. However it has also been demonstrated that the broader themes of those events trade, exploration, military aggression/defense, and so on - were not unique to Britain. The places in which they were unique are historically significant for the territory and peoples outside Britain just mentioned, especially Africans, Caribbean islanders, and North Americans. The British - and thus transatlantic - origin of these places' histories 
make Atlanticism an important tool for their historians. This thesis argues that on the other hand, Atlanticism may not be as significant for specifically British, and more broadly European, topics.

If one accepts, as this thesis argues, that the types of events of eighteenth-century British history took place on the Atlantic were not unique to that body of water, then it becomes clear that Atlantic history is a helpful method for reanalyzing those places, concepts, and peoples with British origins across the Atlantic, but not necessarily for the British themselves. The works on British identity in the literature review above (See Chapter 1, Section II) do not discuss Atlantic history per se, and the concept emerges only tangentially and not on any active part of the authors. While one may argue that approaching those themes of British identity through the lens of the Atlantic is useful, such an approach is ultimately only geographically, and not thematically, unique. In this way, Atlantic history becomes perhaps less crucial for the Europeanist while maintaining vital significance for the Americanist, Caribbeanist, and Africanist studying the European influence on those cultures and the historical legacy created by the Atlantic within them. 


\section{CHAPTER THREE: TOBIAS SMOLLETT'S}

\section{TRAVELS THROUGH FRANCE AND ITALY}

The two historiographical frameworks outlined in the preceding two chapters assist in a better understanding of Tobias Smollett as an example of creating a British identity in the eighteenth century. Specifically, one can point to issues of religion (with its implications for power and authority), general patterns of behavior and public interaction, the construction of a new British identity in the wake of the 1707 Act of Union, and the role of the Atlantic world as illuminating aids to knowing Smollett. This chapter seeks to utilize the perspectives of British identity and Atlanticism to further clarify Tobias Smollett and his utility as an exemplar of the eighteenth-century Briton.

Smollett's observations on France and Italy are rich sources of stereotypically British disdain for the Catholic faith. He includes a scathing attack on Catholicism near the beginning of his travel book, leaving the reader with no doubts as to his opinions (which includes a quick snipe at the cross and the shroud with which the body of Jesus was apparently wrapped, both objects of Catholic veneration):

True it is, the only profane diversions of this place [Boulogne] are a puppetshow and a mountebank; but then their religion affords a perpetual comedy. Their high masses, their feasts, their processions, their pilgrimages, confessions, images, tapers, robes, incense, benedictions, spectacles, representations, and innumerable ceremonies, which revolve almost incessantly, furnish a variety of entertainment from one end of the year to the other. If superstition implies fear, never was a word more misapplied than it is to the mummery of the religion of Rome. The people are so far from being impressed with awe and religious terror by this sort of machinery, that it amuses their imaginations in the most agreeable manner, and keeps them always in good humour. A Roman catholic longs as impatiently for the festival of St. Suaire, or St. Croix, or St. Veronique, as a 
schoolboy in England for the representation of punch and the devil; and there is generally as much laughing at one farce as at the other. Even when the descent from the cross is acted, in the holy week, with all the circumstances that ought naturally to inspire the gravest sentiments, if you cast your eyes among the multitude that croud [sic] the place, you will not discover one melancholy face: all is prattling, tittering, or laughing; and ten to one but you perceive a number of them employed in hissing the female who personates the Virgin Mary. ${ }^{1}$

Perhaps the most significant element of this commentary is Smollett's reduction of Catholicism to a form of social entertainment, portraying the faith as something to do in one's free time. Importantly, the French are not cowed by their faith. This lack of seriousness is, in turn, due to one specific problem: the French are not mature. The apparently immature enjoyment of Catholic practices by the French as presented by Smollett in Letter IV is not consistent, however, and this apparently revolves around the degree to which individual French people adhere to the faith. Just a few pages after his withering attack, Smollett writes that "When I said the French people were kept in good humour by the fopperies of their religion, I did not mean that there were no gloomy spirits among them... the character of a devotee, which is hardly known in England, is very common here."2 Smollett finds moderation to be the appropriate expression of religious belief. Too much happiness exposes the foolishness of Catholicism; too much seriousness, on the other hand, is generally an indicator of hypocrisy, as "I never knew a fanatic that was not an hypocrite at bottom.",

This is not to suggest that Smollett was opposed to Catholic people universally.

His Travels bears out toleration of Catholic individuals. Writing from Nice in December 1763, Smollett recalled an encounter with a Catholic religious:

\footnotetext{
${ }^{1}$ Tobias Smollett, Travels through France and Italy, ed. Frank Felsenstein (New York: Oxford University Press, 1979), Letter IV, 28-29. Originally published London, 1766.

${ }^{2}$ Smollett, Travels, Letter V, 39.

${ }^{3}$ Smollett, Travels, Letter V, 9.
} 
I found a young Irish recolet, in his way from Rome to his own country. He complained, that he was almost starved by the inhospitable disposition of the French people; and that the regular clergy, in particular, had treated him with the most cruel disdain. I relieved his necessities, and gave him a letter to a gentleman of his own country at Montpellier. ${ }^{4}$

This stands in stark opposition to Smollett's rather harsh rant against other Catholics and suggests that Smollett's anti-Catholicism was intellectual rather than personal. The next year (1764), Smollett acknowledges the political utility of the pope by attributing a truce between Charles V and Francis I to the efforts of Pope Paul II. ${ }^{5}$

What appears to be the real problem Smollett has with Catholicism concerns the issue of power, in Smollett's case the perceived power of priests over Catholic lay believers. ${ }^{6}$ Returning to Smollett's abovementioned criticism of Catholic hypocrites the reader sees what Smollett finds wrong in the Catholic system: "The rich devotee has her favourite confessor, whom she consults and regales in private, at her own house; and this spiritual director generally governs the whole family." It is interesting that Smollett does not even approach a criticism of Catholic concepts of confession and forgiveness. He disagrees with the power held by the confessor over the devotee's lifestyle. Thus, Smollett's problem here is connected to authority, not theology. This is part and parcel of the religion-power connection reviewed earlier in this thesis, played out far below the governmental level within individual homes.

\footnotetext{
${ }^{4}$ Smollett, Travels, Letter XII, 109-110.

${ }^{5}$ Smollett, Travels, Letter XVII, 151.

${ }^{6}$ One of the more puzzling episodes in Travels, which bears an explanation that this thesis does not contain space or purpose to approach, is Smollett's attendance at a Mass: "On Christmas-Eve, I went to the cathedral at midnight, to hear high mass celebrated by the new bishop of Nice, in pontificalibus, and stood near two hours uncovered in a cold gallery, without having any cause in the sequel to repent of my curiosity." One can understand that Smollett may have been curious to learn exactly what went on at a Mass, but it is difficult to discern why he did not make any further comment on the event. See Letter XXXV, 288.

${ }^{7}$ Smollett, Travels, Letter V, 39.
} 
This is not to suggest that Smollett did not perceive a problematic relationship between religion and civil authority at those higher, governmental levels. An earlier passage in Travels deals with offering criminals sanctuary in church buildings:

All the churches [in Nice] are sanctuaries for all kinds of criminals, except those guilty of high treason; and the priests are extremely jealous of their privileges in this particular. They receive, with open arms, murders, robbers, smugglers, fraudulent bankrupts, and felons of every denomination; and never give them up, until after having stipulated for their lives and liberty. I need not enlarge upon the pernicious consequences of this infamous prerogative, calculated to raise and extend the power and influence of the Roman church, on the ruins of morality and good order. I saw a fellow, who had three days before murdered his wife in the last month of pregnancy, on the steps of a church in Florence; and nothing is more common, than to see the most execrable villains diverting themselves in the cloysters of some convents at Rome. ${ }^{8}$

The influence of the Church allows Catholic representatives to bargain for the "lives and liberty" of criminals. Smollett makes it abundantly clear that even aside from enhancing the Church's power and wealth behind a mask of human charity, the concept of sanctuary allows criminals to do as they please. Whether Smollett actually intended it or not, his depiction flips the Church upside down: no longer a charitable institution but the very engine of crime and corruption in the world. For a Briton, it was particularly shameful that a religious institution still held so much sway over civil matters - one more mark against the Continentals, who had apparently not yet gotten past these sorts of problems.

Given Smollett's Continental observations, how does one connect his commentary on French and Italian Catholics to British identity? This is clarified in one of the rare criticisms of England in particular and Britain as a whole, wherein Smollett derides English parents who send their children to France for their education. He wrote from Boulogne that

\footnotetext{
${ }^{8}$ Smollett, Travels, Letter XVII, 151.
} 
Here is a square, a town-house, the cathedral, and two or three convents of nuns; in one of which there are several English girls, sent hither for their education.

The smallness of the expence encourages parents to send their children abroad to these seminaries, where they learn scarce any thing that is useful, but the French language; but they never fail to imbibe prejudices against the protestant religion, and generally return enthusiastic converts to the religion of Rome. This conversion always generates a contempt for, and often an aversion to, their own country. Indeed it cannot reasonably be expected, that people of weak minds, addicted to superstition, should either love or esteem those whom they are taught to consider as reprobated heretics. ${ }^{9}$

Here is Smollett's connection between religion and patriotism, the simple incompatibility of Catholicism and Britishness. English children are not averse to their country after having visited France; rather, it is conversion to Catholicism that generates all of this anti-British sentiment in visiting students. Whether the person is Catholic in Nice, Boulogne, London, or Manchester matters not: they will become averse to the "true" Britain anywhere, preferring both the ridiculous spectacle and the legal domination of Catholicism. This was particularly a problem in the case of children sent abroad, as children have always been understandably more receptive of their surrounding influences - even thinking of the eighteenth century, it is only reasonable to expect a child to feel an affinity with their educators and the lessons given by them.

Smollett's commentary on the Catholic faith gives the reader a few hints about his own religious beliefs and provides a certain nuance to Protestantism as a tenet of British identity. Criticism of Colley's lumping together of Protestantism, mentioned above, is somewhat validated by Smollett as a believer. He is clearly opposed to Catholicism; however, Smollett is no Protestant dissenter, either, as he has clear opinions on that group:

I know not whether I may be allowed to compare the Romish religion to comedy, and Calvinism to tragedy. The first amuses the senses, and excites

\footnotetext{
${ }^{9}$ Smollett, Travels, Letter III, 17.
} 
ideas of mirth and good-humour; the other, like tragedy, deals in passions of terror and pity. Step into a conventicler of dissenters, you will, ten to one, hear the minister holding forth upon the sufferings of Christ, or the torments of hell, and see many marks of religious horror in the faces of the hearers. ${ }^{10}$

Catholics are too fanciful; dissenters - especially Calvinists - are too dour. Where does this leave Smollett? If one were to establish an arbitrary spectrum of Christianity with Catholicism at one end and dissenting Protestantism at the other, where would Smollett fall? ${ }^{11}$ Extant evidence suggests he situated himself somewhere in the middle - as more or less an Establishment man.

Smollett bears out some of Haydon's description of Protestant disunity and serves as a vibrant example of the one of the strongest threads running through all the denominations of British Protestantism: one of, if not the most important, goals was simply being not-Catholic. Bickering amongst the various Protestants and non-believers is of little consequence when compared to overall feelings of anti-Catholicism on the part of the British. If one assumes this to be the case, then Smollett's own murky views - still undecided by his biographers - fit well within the given paradigm of Britishness discussed earlier.

But what about British Catholics? Despite the various legal and social impediments faced by British Catholics during the course of the eighteenth century, plenty of them certainly existed. Were these people any less British than Tobias Smollett or any other non-Catholic Briton? From Smollett's point of view, the answer was yes. Aside from buying into the religion of ridiculous spectacle, blatant hypocrisy, and improper expectations of power and submission on the part of the pious, Catholics owed

\footnotetext{
${ }^{10}$ Smollett, Travels, Letter IV, 30.

${ }^{11}$ I specifically say spectrum of Christianity as that is the most applicable religion to employ for this metaphor, and the one he mentions most often. Smollett only mentions Judaism and Islam in passing, and those brief moments are indicative of Smollett's position as an outsider. See Letter XIII, 117.
} 
their allegiance to a person and a place outside Britain: throughout Travels, Smollett refers to Catholicism as "the religion of Rome." ${ }^{.2} \mathrm{He}$ cannot take Catholicism seriously because it is both false as a religion and foreign to a "true" British identity.

Smollett's criticism of Catholicism ranges from the ceremonial to the juridical; this latter aspect of his commentary brings him into eighteenth-century anti-Catholicism on the grounds that that particular power structure - one of unquestioning obedience and non-debate, both religious and civil - was very clearly un-British, as Britons were quite content with their parliamentary government and non-foreign religious instruction. Ultimately this indicates that Smollett was not an opponent of Catholics, per se - after all, he did have complimentary words for Paul II and offered a helping hand to an Irish religious in need - but of "popery," that strategy defined as the manipulation of superstition by the Tombses in Chapter 1 .

Religion is not the only focus of Smollett's dislike for the French. There were plenty of other reasons that the traveling Scot did not like the Continent, and they contribute to that category of "Otherness" against which the British defined themselves and demonized their national counterparts across the English Channel. One of Smollett's chief complaints was the high financial penalty incurred during travel through France that arose directly out of being "Other" to the French: "The ordonnances [customs laws] of France are so unfavourable to strangers, that they oblige them to pay at the rate of five per cent. for all the bed and table linen which they bring into the kingdom, even though it has been used."13 This example of what Smollett perceived to be maltreatment was not specific to the British, though; the British were subject to even more on a non-official

\footnotetext{
${ }^{12}$ Smollett, Travels, Letter IV, 29.

${ }^{13}$ Smollett, Travels, Letter II, 53.
} 
level. Writing from Boulogne-sur-mer, Smollett complained of greedy innkeepers "one would imagine the French were still at war with the English, for they pillage them without mercy." ${ }^{" 14}$ Of course this was only possible due to the wealth of the English: without rich customers, the French would have had nobody to overcharge. Smollett admonishes English travelers to be aware of their appearance abroad and make every effort to appear frugal; otherwise, the French will only continue to charge exorbitant prices of the traveler: "Without all doubt, it must be owing to the folly and extravagance of English travellers, who have allowed themselves to be fleeced without wincing, until this extortion is become authorized by custom." 15

Smollett's dissatisfaction with foreign accommodations was caused not only by high prices. Smollett was rarely happy with whatever inn at which he happened to stay, both in France and Italy. ${ }^{16}$ While in Italy Smollett even brought out the racial attitudes of some Britons at the time in one comment on an inn:

The house was dismal and dirty beyond all description; the bed-cloaths filthy enough to turn the stomach of a muleteer; and the victuals cooked such a manner, that even a Hottentot could not have beheld them without loathing. ${ }^{17}$

French inns fared no better, even in comparison with the worst on offer in England:

This was such a bad specimen of French accommodation [an inn in Boulognesur-mer], that my wife could not help regretting even the inns of Rochester, Sittingbourn, and Canterbury: bad as they are, they certainly have the advantage, when compared with the execrable auberges of this country, where one finds nothing but dirt and imposition. ${ }^{18}$

\footnotetext{
${ }^{14}$ Smollett, Travels, Letter I, 52.

${ }^{15}$ Smollett, Travels, Letter XXXIX, 306. Felsentstein comments on this problem in his introduction to Travels, writing "In England, the French were still the object of considerable suspicion, while in France the common people took every opportunity to cash in on the extravagant habits of the British "invasion." See Letter XVII.

${ }^{16}$ Smollett did find some comfort while abroad; however, this was usually when he rented a house and furnished and maintained it himself, rather than relying on an innkeeper.

${ }^{17}$ Smollett, Travels, Letter XXXIV, 279.

${ }^{18}$ Smollett, Travels, Letter I, 51-52. Immediately after this complaint, Smollett makes the comment about the French thinking they are still at war with the English.
} 
One wonders how Smollett found the will to continue on after this apparently deplorable experience.

Smollett's condemnation of all French accommodation after the experience of one inn is an example of a pattern of translating individual negative experiences onto a nation as a whole. Oftentimes the reader finds Smollett suffering some negative experience and relaying it in terms of "the French" as a whole; thus one reads of "the execrable auberges of this country," or Smollett's conviction that the French act as though they are still at war with the English after his rather limited experience in Boulougne-sur-mer. Within the contexts of those letters that discuss French Catholics, the reader gets the same impression as Smollett writes to the effect of "this is what I saw, and therefore I condemn all the French for it." In these judgmental instances Smollett is not opposed to forming an opinion of an entire people on the basis of one or two distasteful circumstances.

On that evidence alone, the reader would not be blamed for assuming Smollett to be a rather rash judge of national character. However, he was capable of nuanced distinctions and finding exceptions to the apparently inferior status of the French. He was particularly impressed by some of France's leading statesmen (even while professing an inability to comprehend the admiration of Louis XIV):

Through all France one meets with statues and triumphal arches erected to Louis $\mathrm{XIV}$, in consequence of his victories; by which, likewise, he acquired the title of Louis le Grand. But how were those victories obtained? Not by any personal merit of Louis. It was Colbert who improved his finances, and enabled him to pay his army. It was Louvios that provided all the necessities of war. It was a Conde, a Turenne, a Luxemburg, a Vendome, who fought his battles... it was Colbert that improved the marine, instituted manufactures, encouraged commerce, undertook works of public utility, and patronized the arts and sciences. ${ }^{19}$

\footnotetext{
${ }^{19}$ Smollett, Travels, Letter XII, 129.
} 
Importantly, Smollett does not offer these men as examples of people the French respect; his description flows from his own admission that they had done great things.

Unfortunately it was not men like the above that Smollett encountered on his journey through France. The traveling Scotsman interacted, by and large, with those "everyday" French people whose character and lifestyle Smollett found so disagreeable to his own.

Smollett also throws the French and Italians into the "Other" category through the concept of British propriety, which can be summarized by what Smollett wrote in Letter VI from Paris: "In the character of the French, considered as a people, there are undoubtedly many circumstances truly ridiculous. ${ }^{, 20}$ Smollett's attitude toward the French exposes a sense of greater maturity, as he compares French Catholics to English schoolboys. ${ }^{21}$ Aside from the example of the weak-minded French peasants taking part in religious customs, his accusations of immaturity take sharpest aim at what he perceives to be French vanity. ${ }^{22}$ Smollett names vanity as a trademark characteristic of the French, so deeply ingrained into the culture that he muses "I wonder there should be a term to express it ["modesty, or diffidence"] in their language.",23

Letter VII contains the heart of Smollett's opinions toward French behavior. The perceived vanity of Frenchmen was wrapped up in notions of what Smollett termed politeness and the French inclination to violate the social protocol by which Smollett presumably operated himself. His commentary offers the reader an insight into the

\footnotetext{
${ }^{20}$ Smollett, Travels, Letter VI, 51.

${ }^{21}$ Smollett, Travels, 29.

${ }^{22}$ To be fair, Smollett displayed an opposition to vanity on the part of any person, not just a French man or women: "When the natives of France come to London, they appear in all public places, with cloaths made according to the fashion of their country, and this fashion is generally admired by the English...certainly, in point of true taste, the fashions of both countries are equally absurd."See Letter VI, 52.

${ }^{23}$ Smollett, Travels, Letter VII, 61.
} 
corresponding qualities that it is safe to assume Smollett felt were embodied by the

British:

If I was obliged to define politeness, I should call it, the art of making one's self agreeable. I think it an art that necessarily implies a sense of decorum, and a delicacy of sentiment. These are qualities, of which (as far as I have been able to observe) a Frenchman has no idea; therefore he never can be deemed polite, except by those persons among whom they are as little understood. His first aim is to adorn his own person with what he calls fine cloaths, that is the frippery of the fashion. It is no wonder that the heart of a female, unimproved by reason, and untinctured with natural good sense, should flutter at the sight of such a gaudy thing, among the number of her admirers: this impression is enforced by fustian compliments, which her own vanity interprets in a literal sense, and still more confirmed by the assiduous attention of the gallant, who, indeed, has nothing else to mind. A Frenchman in consequence of his mingling with the females from his infancy, not only becomes acquainted with all their customs and humours; but grows wonderfully alert in performing a thousand little offices, which are overlooked by other men, whose time hath been spent in making more valuable acquisitions. He enters, without ceremony, a lady's bedchamber, while she is in bed, reaches her whatever she wants, airs her shift, and helps to put it on. ${ }^{24}$

The highlight of his rant against the vanity of French men is Smollett's assertion that "A Frenchman will sooner part with his religion than with his hair, which, indeed, no consideration will induce him to forego.",25

Despite claiming that he was not judging an entire people on the merits of limited examples, Smollett does just that when approaching Italian behavior and the concept of the cicisbeo: $:^{26}$

... certain it is, every married lady in this country has her cicisbeo, or servente, who attends her every where, and on all occasions; and upon whose privileges the husband dares not encroach, without incurring the censure of the whole community. For my part, I would rather be condemned for life to the gallies, than exercise the office of a cicisbeo, exposed to the intolerable caprices and dangerous resentments of an Italian virago. I pretend not to judge of the national character, from my own observation; but, if the portraits drawn by Goldoni in

\footnotetext{
${ }^{24}$ Smollett, Travels, Letter VII, 61.

${ }^{25}$ Smollett, Travels, Letter VII, 64.

${ }^{26}$ Smollett defines cicisbeo only obliquely and by leaving it to the reader's imagination: "The husband and the cicisbeo live together as sworn brothers; and the wife and the mistress embrace each other with marks of the warmest affection. I do not choose to enter into particulars." See Travels, Letter XVII, 168.
} 
his Comedies are taken from nature, I would not hesitate to pronounce the Italian women the most haughty, insolent, capricious, and revengeful females on the face of the earth. ${ }^{27}$

Surely, then, a British man would never consider sacrificing his hair before renouncing his faith; no British woman would be so stupid as to be deceived by some gaudy bauble presented by a man in her pursuit; and no British women would request a British man to fulfill the role of cicisbeo. Smollett also hints at a strict division of gendered space in the British mindset. As he is so outraged by the French man's easy violation of female space, it is implied that Smollett would never dream of entering a woman's bedroom unannounced.

This is significant in light of de Ritter's article on the gender-influencing effects of the Grand Tour. As de Ritter explains, one of the fears that critics of the Grand Tour held was that British travelers would have their very characters modified by traveling in Europe, with men coming back more feminine than when they left. Smollett thus apparently embodies the ability to travel "correctly": he is not taken in by the customs and mannerisms of the local people and thus maintains an appropriate Britishness despite the harmful influences by which he is surrounded. De Ritter quotes Boswell as wanting to rid himself of any particularly "rude" habits and adopt the character of those he encounters, thus becoming a good example of the effects of travel. Smollett's opinion is the exact opposite: he wanted to travel, and he wanted to extract the benefits of the areas he visited, but he was far from wanting to become anything like the French or the Italians while he was on the continent. This is not to say that Smollett found no redeeming qualities in the French: indeed it was possible for Smollett to view certain French people as tolerable contemporaries. This toleration came at the price of time, however:

${ }^{27}$ Smollett, Travels, Letter XXVII, 228. 
I have often heard it observed, that a French officer is generally an agreeable companion when he is turned of fifty. Without all doubt, by that time, the fire of his vivacity, which makes him so troublesome in his youth, will be considerably abated, and in other respects, he must be improved by his experience. ${ }^{28}$

Thus it was possible for Smollett to find the continental "Other" agreeable - but only if the "Other" rose to Smollett's standards.

Smollett did play into a sense of British patronization mentioned earlier, especially when he traveled to Italy and encountered aspects of the country related to the ancient Romans. He tells the aspiring traveler that "strangers are generally advised to employ an antiquarian to instruct them in all the curiosities of Rome; and this is a necessary expence, when a person wants to become a connoisseur in painting, statuary, and architecture. ${ }^{.29}$ Thus it is necessary for an antiquarian to point out the glories of Rome - not a contemporary tour guide, but one versed in the past who can highlight the glory of a Rome that was. The modern achievements in Italy that Smollett observed - St. Peter's, the Sistine Chapel, the tower at Pisa - are good enough on their own merit, but Smollett still does not find them to exceed anything in Britain. ${ }^{30}$

Perhaps more importantly, and where Smollett diverges from the current historiography on British travelers reveling in Italy's past, is Smollett's shrugging attitude to some of the ancient monuments and structures which remained. In fact, speaking of those Romans, Smollett says in comparison

All the precious monuments of art, which have come down to us from antiquity, are the productions of Greek artists. The Romans had taste enough to admire the arts of Greece, as plainly appears by the great collections they made of their

\footnotetext{
${ }^{28}$ Smollett, Travels, Letter XV, 152. Even this rather condescending comment was qualified, as Smollett continued "But there is a fundamental error [bigotry] in the first principles of his education, which time rather confirms than removes."

${ }^{29}$ Smollett, Travels, Letter XXIX, 242.

${ }^{30}$ Specifically, Smollett says that St. Peter's would be much more impressive if it wasn't crowded by other structures, that the tower at Pisa is not all that curious as it was designed to lean, and that the Sistine Chapel's ceiling is too confusing to the eye. See Letters XXVII, XXXI, and XXXII, respectively.
} 
statues and pictures, as well as by adopting their architecture and musick: but I do not remember to have read of any Roman who made a great figure either as a painter or a statuary. It is not enough to say those professions were not honourable in Rome, because painting, sculpture, and musick, even rhetoric, physic, and philosophy were practised and taught by slaves. The arts were always honoured and revered at Rome, even when the professors of them happened to be slaves by the accidents and iniquity of fortune. The business of painting and statuary was so profitable, that in a free republic, like that of Rome, they must have been greedily embraced by a great number of individuals: but, in all probability, the Roman soil produced no extraordinary genius for those arts. Like the English of this day, they made a great figure in poetry, history, and ethics; but the excellence of painting, sculpture, architecture, and music, they never could attain. ${ }^{31}$

It was in this way that Smollett professed an admiration for Rome's less concrete achievements - "poetry, history, and ethics" as a "free republic" - but was among those not impressed by some of the more tangible remains: in simple terms of visible accomplishment, the Greeks got there first. In an episode later parodied mercilessly by Laurence Sterne in his Sentimental Journey, Smollett declares "I was much disappointed by the sight of the Pantheon, which, after all that has been said of it, looks like a huge cockpit, open at the top."32 It was thus that Smollett found no particular merit to Italy as it stood in his day. While he admitted that republican Rome had accomplished something, most of the things which admiring Britons went to see - modern Italian art or ancient remains - were nothing particularly impressive to Smollett.

Of course, the discussion on Smollett's interpretation of Britishness and his assumption of British superiority makes generous assumptions as to the word "British," and his Travels offers multiple examples of the forces at play in forging that new identity. Chapter 1 examined some of the guidelines of British identity, including constructing this identity along English lines. It would seem that Smollett viewed England and Britain as

\footnotetext{
${ }^{31}$ Smollett, Travels, Letter XXXIII, 272.

${ }^{32}$ Smollett, Travels, Letter XXXI, 257.
} 
two nearly identical entities. Time and again, the reader finds references to the superiority of Britain and England as in this boast of British military power. Here Smollett freely swaps back and forth between speaking of Britain and England, apparently conveying the same idea with each:

If he [the King of Sardinia] is really determined to make the most of the maritime situation of his dominions, as well of his alliance with Great-Britain, he ought to supply his ships with English mariners, and put a British commander at the head of his fleet. He ought to erect magazines and docks at Villa Franca; or if there is no conveniency for building, he may at least have pits and wharfs for heaving down and careening; and these ought to be under the direction of Englishmen, who best understand all the particulars of marine œconomy. ${ }^{33}$

This passage gives no indication that Smollett intends any difference between the terms English and British. It thus seems that Krishan Kumar's theory is correct when applied to the case of Tobias Smollett and the national identity of the British. An important question to then ask is why Smollett would assume the British mantle and engage in this swapping of English and British so freely.

It is not only Smollett's writings in Travels through France and Italy that bear out this elision, as his life in general is a case study of British identity in the eighteenth century. His early life was spent in Scotland; he spent a great deal of time away from the home island in the service of the British; and eventually traveled back to England, where he remained for a number of years before going to Italy at the end of his life. One wonders, though, why he speaks so often (and usually so highly) of Britain or England in his Travels - references to Scotland are few and far between, surprisingly so given Smollett's heritage.

Recall that Kahrl's biography of Smollett indicated that his literary career was conducted in a manner intended to not offend his largely English audience, an effort to

${ }^{33}$ Smollett, Travels, Letter XIV, 130. 
avoid incurring the wrath of English anti-Scots bigotry. This may go some distance toward explaining the relative paucity of references to Scotland in Travels; in fact, most of Smollett's Scottish mentions are somewhat derogatory. While deriding the people of Boulogne, Smollett writes "Indeed they are utter strangers to what we call common decency; and I could give you some high-flavoured instances, at which even a native of Edinburgh would stop his nose. ${ }^{.34}$ Again describing the pathetic state of France - this time turning his nose up from Nice - Smollett writes of a public lavatory: "This is a degree of beastliness, which would appear detestable even in the capital of NorthBritain." ${ }^{235}$ Smollett seems to believe that public lavatories in "North Britain" are particularly unpleasant when compared to other British facilities, but the lavatory in Nice was especially malodorous. Important, Smollett speaks not of Scotland - he says "NorthBritain." This declaration is a clear example of subordinating more regional - English or Scottish - identities within the larger British identifier, but does not explain why Smollett would say such a thing.

It is possible that Smollett wrote these things in an attempt to ingratiate himself with an English audience - after all, he did need to sell books. However, the evidence of Smollett's writing in Travels and his general course of life indicate that his elision of Britishness and Englishness has much more to do with a proactive choice to assume his status as a Briton in a manner more English than Scottish.

Chapter 1 saw Colley's discussion of Britons from the so-called "Celtic fringe" moving to England in order to assume a greater role in the new country. Tobias Smollett was no exception to this pattern, as he set out from Scotland to settle in London with

\footnotetext{
${ }^{34}$ Smollett, Travels, Letter V, 33.

${ }^{35}$ Smollett, Travels, Letter XII, 107-108. Emphasis mine.
} 
hopes of both establishing a medical practice and also indulging his artistic impulses. He felt drawn to the capital because he knew his prospects for success were much better there than in Scotland: this was a decision based on his own aspiration to do well in life and a love for English literature. The keys to success lay south, not at home, and Smollett's career as an author benefited from the move. Thus Smollett fits well into this general movement from the periphery to the center on the part of England's new partners in the venture of Britain.

But why did Smollett not maintain a bold and unapologetic Scottishness in his Travels? The book is full of references to various nations and peoples; had he really wanted to, it would not have appeared out of place within Travels to extol the virtues of Scotland, especially given the hostile climate of England at the time. It is only reasonable that people in a relatively different place struggle to maintain their own identity and often overcompensate for the effects of assimilation by expressing their difference that much louder. Was Smollett not a good candidate for this sort of foreign expression of identity in a different place?

Smollett's social circles would indicate that perhaps it was not all that necessary for the man to maintain a vehemently Scottish identity - both in his everyday life in London and Chelsea and in his Travels - because his needs for acceptance as a Scot were already met without having to boldly declare his Scottishness. Knapp's biography recalls that "the circle of Smollett's friends here assembled [in London] was made up almost entirely of Scotsmen." ${ }^{36}$ Smollett's status as a member of a relatively successful circle of Scottish Britons could provide all the Scottish affirmation he needed: there was no need

\footnotetext{
${ }^{36}$ Knapp, Doctor of Men and Letters, 84.
} 
to express his difference as a response to whitewashing assimilation when he was able to be comfortably Scottish with his friends on a regular basis. ${ }^{37}$

Aside from this comfort in social circles, it is likely that an element of embarrassment, or at least disappointment, in his Scottish heritage when compared to that of the Englishmen among whom Smollett lived informed his elision of English and British. Kahrl's biography highlights Smollett's confession to the reader in Travels concerning a trip he had made home at one point: "When I first revisited my own country, after an absence of fourteen years, I found every thing diminished... and I could scarce believe my own eyes." ${ }^{\text {38 }}$ Perhaps because of this disappointing memory Smollett felt that English Britishness was preferable to the Scottish iteration.

Tobias Smollett may also have felt a feeling similar to James Boswell, who as de Ritter quotes was "disgusted" by his "Scotch tones and rough and roaring freedom of manners" unleashed while traveling on the continent. ${ }^{39}$ This would indicate that Smollett's - and indeed many other Scots' - move to England initiated a desire to acquire the mannerisms of an Englishman and leave behind what were perceived to be provincial modes of behavior and speech. In terms more apparent to contemporary readers of this thesis, one thinks of an American from the "deep" South moving to a metropolis on the eastern seaboard: gone is the rural twang, banished in hopes of gaining acceptance among newfound social groupings.

\footnotetext{
${ }^{37}$ Kahrl's biography suggests that this comfort among friends may have also contained an element of feeling outcast from non-Scots. See Kahrl, Traveler-Novelist, 71-72, and Chapter 1 of this thesis, p. 13. ${ }^{38}$ Kahrl, Traveler-Novelist, 63; Smollett, Travels, Letter VI, 45.

${ }^{39}$ See Chapter 1, note 18.
} 
A particular example of Smollett's boasting will serve as a bridge into a significant component of his Travels, allowing an analysis of the book as an example of Atlantic history and its application. Writing from Nice on the topic of Italy, Smollett says:

Rome has nothing to fear from the catholic powers, who respect it with a superstitious veneration as the metropolitan seat of their religion: but the popes will do well to avoid misunderstandings with the maritime protestant states, especially the English, who being masters of the Mediterranean, and in possession of Minorca, have it in their power at all times, to land a body of troops within four leagues of Rome, and to take the city, without opposition. ${ }^{40}$

Foreign, Catholic, and militarily weak: Smollett attacks them all in this brief assertion of Britain's superiority. From one direction, this represents just one more example of Smollett's national pride; on the other, it hints at Smollett's view and awareness of the world.

Smollett made a point to mention the British possession of Minorca, and this is almost surely not only for geographic reasons: Minorca had been ceded to the British in the Treaty of Paris in $1763 .^{41}$ The British were capable of landing troops so close to the pope as a direct result of victory in that war, a war of which Smollett was well aware and with which he was quite familiar. During his time in Boulogne Smollett spoke with Frenchmen who had fought against the British in what Smollett refers to simply as "the war"; he observes that the population of Boulogne was substantially affected by combat with the British, as "there is hardly a captain of an armateur in Boulogne, who has not been prisoner in England five or six times in the course of the war." "The war" had clearly become a common fixture of British historical awareness, in much the same way that an American reader in the later 1940s would understand what was meant by "the

\footnotetext{
${ }^{40}$ Smolett, Travels, Letter XXX, 259.

${ }^{41}$ See Article XII of the Treaty, which declares that Minorca shall be returned "to his Brittanick Majesty."

"Treaty of Paris," (1763), Article XII. http://avalon.law.yale.edu/18th century/paris763.asp.

${ }^{42}$ Smollett, Travels, Letter V, 32.
} 
war" that had just ended. Smollett's familiarity with the events of the Seven Years' War places Travels within the boundaries of Atlantic history: true enough, the account only discusses France and Italy, but the presence of Atlantic entities and knowledge of the subject illuminates Smollett's connections to that wider world.

Aside from Smollett's residence and travels in thoroughly "Atlanticized" countries - Britain, France, and the Italian states - he also served aboard British military ships in the West Indies. It was thus that Smollett became a living part of the Atlantic world as historians understand it now. His knowledge of territories and peoples outside of Britain and France hint at his integration into the Atlantic world and show that Atlantic concepts were on his mind (albeit unconsciously). Throughout Travels, the reader finds Smollett mentioning aspects of transatlantic places, the events of the war, and the war's results: "In... Boulogne, there is a number of poor Canadians, who were removed from the island of St. John, in the gulph of St. Laurence, when it was reduced by the English"; "Wild-boar is sometimes found in the mountains; it has a delicious taste, not unlike that of the wild hog in Jamaica"; and, comparing Nice to a place quite far removed from it, "In summer, the air is cooled by a regular sea-breeze blowing from the east, like that of the West-Indies. ${ }^{\circ 44} \mathrm{He}$ was also well aware of the lasting effects of the Seven Years' War, offering this explanation of the economic situation in Marseilles at the time of his visit:

Notwithstanding the great face of business at Marseilles, their trade is greatly on the decline; and their merchants are failing every day. This decay of commerce is in a great measure owing to the English, who, at the peace, poured in such a quantity of European merchandize into Martinique and Guadalupe, that when the merchants of Marseilles sent over their cargoes, they found the markets overstocked, and were obliged to sell for a considerable loss. Besides, the French colonists had such a stock of sugars, coffee, and other commodities lying

\footnotetext{
${ }^{44}$ Smollett, Travels, Letter V, XIIII; Letter XVII, 157; Letter XXIV, 195, respectively.
} 
by them during the war, that upon the first notice of peace, they shipped them off in great quantities for Marseilles. I am told that the produce of the islands is at present cheaper here than where it grows; and on the other hand the merchandize of this country sells for less money at Martinique than at Provence. ${ }^{45}$

The economic effects of the Seven Years' War become clear: the Marseilles export market had more or less collapsed. Smollett was aware that this was a direct outcome of British victory. Travels gives ample evidence that Smollett understood the integration of Britain and France into a thoroughly Atlantic world; while his comments on the Atlantic aspects of those countries admittedly play second fiddle to the overwhelming assertions of British superiority - economic, cultural, and military - over the French, the Atlantic component is present and important nonetheless.

Earlier, questions were raised about the logical limits of Atlantic history as a specific field of historical inquiry: how far, both geographically and conceptually, can Atlantic history be pushed? To what extent do the thematic and the geographic considerations of Atlantic history coincide? Do they simply coincide, or are they more intimately linked? By reviewing the work of several historians in or related to the field, the conclusions reached above were that 1) thematically, the Atlantic is not a particularly unique entity as the types of activities and events that took place within the Atlantic and bordering countries were not limited only to that area; and 2) while the Atlantic Ocean is a useful geographical tool by which to imply spatial limitations, there is a clear danger of stretching Atlantic connections beyond the oceanic basin to the point that they no longer really make sense. Smollett's Travels provides a helpful example of these problems and a concrete way to think about the questions surrounding the application of an Atlantic perspective.

${ }^{45}$ Smollett, Travels, Letter XXXIX, 328-329. 
The Atlantic played a significant role in Smollett's own life: British involvement in the Atlantic and the Caribbean provided Smollett with employment and life experience. The time Smollett spent doing "Atlantic activities" provided him with a frame of reference for his later experiences as put down in Travels; thus, the reader finds him comparing the winds of Nice with the climate of the West Indies and French animals with those found in Jamaica. Smollett's comprehension of the importance and consequences of the Seven Years' War provided him with valuable information when interpreting the contemporary state of France, allowing real British superiority in the wake of the war to enhance Smollett's national opinion. Was, then, the British Atlantic world such a major component in British superiority, both objectively and through Smollett's subjective experience?

Yes and no. The events taking place in and around the Atlantic during the eighteenth century boosted Britain's strength and self-pride immensely. The defeat of the French and Spanish during the Seven Year's War was one of the defining moments of eighteenth-century British history; for Smollett himself, the Atlantic context was useful this is where Smollett was able to draw some of the most colorful examples of British strength. However, one is able to recognize the limits of Atlantic history by acknowledging that large parts of Smollett's Travels can be safely separated from an Atlantic context. Surely the religious, artistic, and behavior-orientated dimensions of his commentary can be approached from an entirely non-Atlantic perspective. In this way, the Atlantic world was not the most important component of Smollett's worldview, and one can rather easily imagine a rewrite of Travels with no mention of the Atlantic or the events pertaining thereto. 
Smollett's account thus serves as a useful reminder of the problem highlighted above: it is tempting to push Atlantic history into places in which it does not comfortably belong. If one does this, Tobias Smollett and his French and Italian travels become excellent candidates for inclusion in the canon of Atlantic history. However, it can be argued that while an Atlantic perspective is useful to understanding one portion of Smollett's worldview, the Atlantic world as a definite field of historiography is not crucial to understanding the man or Travels as a whole. True enough the Atlantic activities of Britain were important to Smollett's worldview, but had those activities taken place anywhere else - had Smollett seen French veterans of Pondicherry, or compared the winds of Nice to an Indian sea breeze - the effect would have been the same. The geographical comparison was incidentally due to Smollett's own experiences. In this way Tobias Smollett and his Travels illustrate rather well the relative strengths and weaknesses of the Atlantic perspective, illuminating for the historian the limits of that viewpoint and its integration with concepts of British identity. 


\section{CONCLUSION}

This thesis has attempted to locate Tobias Smollett's role in understanding eighteenth-century British identity, using his Travels through France and Italy as something of a sourcebook of contemporary British thought.

Chapter 1 provided an overview of biography on Smollett and the more significant themes that find discussion in Smollett's Travels. As the field of British identity and self-conception advances, Smollett's Travels offers scholars of both history and literature an excellent opportunity to glimpse the process of understanding one's self as a Briton; Smollett's Scottish descent provides an even better perspective as he came from what was then perceived as one of England's "junior partners" in the United Kingdom.

Chapter 2 examined several significant aspects of eighteenth-century British identity as experienced in the British archipelago and beyond. These markers of identity were significant, but not definitive in the case of every single Briton. Not every British man, woman, and child was Protestant; not every Briton set sail on the ocean, met a sailor, or even saw the open sea during his lifetime; not every Briton feared the imminent arrival of the French army headed by the king or the pope (or, God forbid, both).

Ultimately, historians of Britain - even the most enthusiastically patriotic of them - must concede that not every eighteenth-century Briton thought of herself as such. Certainly there were still plenty of English, Scottish, Irish, and Welsh inhabitants of the British Isles; a good number of them were content with that descriptor and may never even have 
conceived of the terms "Great Britain" or "United Kingdom." There were surely a number of emigrants who willingly surrendered their previous identity and assumed the status of North American, or Virginian, or Georgian - for them, both Britain and Britishness were in the past.

Despite these concessions, those markers of identity as seen in Chapter 1 were nonetheless highly significant in the development of Britain in the eighteenth century. Naval power and interactions with non-Protestant peoples dominated British expansion and international relations. In all cases, the "other" - wherever and however it was encountered - provided an excellent medium through which to define British identity. For these reasons, the markers of British identity discussed in Chapter 1 - significant, but not all-encompassing - are crucial to the way in which historians now study eighteenthcentury Britain.

Chapter 2 serves as an example of the continuing debate within the profession on the exact layout of Atlantic history; it should be clear that the nature of Atlantic history is far from settled. While such a debate necessarily strays from more direct historical projects on specific topics, it is nonetheless an important discussion about the tools of the trade and helps historians more narrowly define the ways in which they look at the past. The appearance of Atlantic history as a methodological tool drastically changed the research and writing of the Atlantic, and just how that appearance changed historiography is still being fought out. The conclusions at which this thesis arrives are one interpretation of Atlantic history as a field of inquiry: while it is necessary to recognize the substantial risk of pushing the Atlantic perspective too far, there is great value in that approach once certain limitations are acknowledged. Research within those limitations 
can lead (and has led) to some of the best work in multiple national and thematic fields; the scholars and work examined above highlight the risks of both overextending Atlanticism and refusing to utilize that framework.

By placing elements of British identity within an Atlantic context and examining the travel narrative of Tobias Smollett, the utility of turning an Atlantic eye toward British history and identity is clarified and Smollett's role in exposing British identity and his own perception of such gains importance. It should be clear from this thesis that Smollett fits rather well within the established confines of eighteenth century British history: his feelings of British superiority, for all the reasons outlined in the previous chapter, make him something of a "typical" Briton and cast him as an easy example of what it meant to be British in the eighteenth century, especially in the characteristics detailed in this analysis of Travels. Importantly, though, the combination of Smollett's sweeping generalizations with his more nuanced exceptions and justifications for his opinions add to a richer understanding of eighteenth-century British identity. True enough Smollett felt vastly superior in his Britishness; however, Travels offers the scholar both colorful reasons for this perceived superiority and more detailed explanations of the sources of this feeling. Smollett was often vehemently anti-Catholic, and Travels explains why and under what conditions; Smollett shows immense pride in being British, and his life and his Travels detail the way and the reasons for which he assumed that national appellation; and Smollett showed over and over again why the French and Italian "other" was so detestable, with Travels giving multiple reasons why that was so. 
This thesis is admittedly the brief contribution of a novice historian to one of the most contentious and important historiographical debates of today. The fields of British identity and Atlantic history are two of the most exciting to historians in the twenty-first century - especially colonialists - and each field has made an enormous impact on the ability of scholars to write fresh histories of established subjects. It is the sincere hope of the author that this small project may serve as a component of more substantial and detailed works on British identity, Tobias Smollett, and the application of Atlanticism to various historical fields. 


\section{REFERENCES}

\section{PRIMARY SOURCES}

Smollett, Tobias George. Travels through France and Italy. Edited by Frank Felsenstein. New York: Oxford University Press, 1979. Originally published London, 1766.

Sterne, Laurence. A Sentimental Journey through France and Italy by Mr. Yorick. Edited by Gardner D. Stout, Jr. Berkeley: University of California Press, 1967. Originally published London, 1768.

Thomson, James. "Rule Britannia." In "Alfred," masque by Thomas Arne and James Thomson, 1740 .

“Treaty of Paris." 1763. http://avalon.law.yale.edu/18th_century/paris763.asp.

\section{MONOGRAPHS}

Anderson, Fred. The War that Made America: A Short History of the French and Indian War. New York: Penguin, 2006.

Bailyn, Bernard. Atlantic History: Concepts and Contours. Cambridge, MA: Harvard University Press, 2005.

Bailyn, Bernard. The Peopling of British North America. New York: Alfred A. Knopf, Inc., 1986.

Black, Jeremy. Italy and the Grand Tour. New Haven: Yale University Press, 2003.

Colley, Linda. Britons: Forging the Nation 1707-1837. New Haven: Yale University Press, 2008.

Elliott, J. H. Empires of the Atlantic World: Britain and Spain in America 1492-1830. New Haven: Yale University Press, 2006.

Hurd, Richard. Dialogues on the Use of Foreign Travel; Considered as a Part of an English Gentleman's Education: Between Lord Shaftesbury and Mr. Locke. London: A. Millar, 1764 
Kahrl, George M. Tobias Smollett: Traveler-Novelist. Chicago: University of Chicago Press, 1945.

Knapp, Lewis M. Tobias Smollett: Doctor of Men and Letters. Princeton: Princeton University Press, 1949.

Miller, John. James II. New Haven: Yale University Press, 2000.

Muldoon, James S. Empire and Order. New York: St. Martin's Press, 1999.

Plumb, J. H. Men and Places. London: Cresset, 1963.

Porter, Andrew. Religion versus Empire? British Protestant Missionaries and Overseas Expansion, 1700-1914. New York: Manchester University Press, 2004.

Smeaton, Oliphant. Tobias Smollett. New York: Charles Scribner's Sons, 1897.

Strong, Rowan. Anglicanism and the British Empire, c. 1700-1850. New York: Oxford University Press, 2007.

Tombs, Robert and Isabelle. That Sweet Enemy: The French and the British from the Sun King to the Present. New York: Alfred A. Knopf, 2007.

Trease, Geoffrey. The Grand Tour. Chicago: Holt, Rinehart and Winston, 1967.

\section{SOURCES FROM EDITED COLLECTIONS}

Andrien, Kenneth. "The Spanish Atlantic System." In Atlantic History: A Critical Appraisal, edited by Jack P. Greene and Philip D. Morgan, 55-79. New York: Oxford University Press, 2009.

Armitage, David. "Three Concepts of Atlantic History." In The British Atlantic World, 1500-1800, edited by David Armitage and Michael Braddick, 11-27. New York: Palgrave Macmillan, 2002.

Boucé, Paul-Gabriel. "Eighteenth and Nineteenth-Century Biographies of Smollett." In Tobias Smollett: Bicentennial Essays Presented to Lewis M. Knapp, edited by G. S. Rousseau and P.-G. Boucé, 201-230. New York: Oxford University Press, 1971.

Buckner, Timothy. "The Slave Trade's Apex in the Eighteenth Century." In The Atlantic World, 1450-2000, edited by Toyin Falola and Kevin D. Roberts, 96-113.

Bloomington: Indiana University Press, 2008. 
Chaplin, Joyce. "Enslavement of Indians in Early America." In The Creation of the British Atlantic World, edited by Elizabeth Mancke and Carole Shammas, 45-70. Baltimore: The Johns Hopkins University Press, 2005. . "Race." In The British Atlantic World, 1500-1800, edited by David Armitage and Michael Braddick, 154-172. New York: Palgrave Macmillan, 2002.

Graves, Donald. “'A perfect good understanding between the Army and the Navy': British Seapower and the Siege of Quebec." In Fighting at Sea: Naval Battles from the Age of Sail and Steam, 4-51. Cap-Saint-Ignace, Quebec: Robin Brass Studio, 2008

Greene, Donald. "Smollett the Historian." In Tobias Smollett: Bicentennial Essays Presented to Lewis M. Knapp, edited by G. S. Rousseau and P.-G. Boucé, 2556. New York: Oxford University Press, 1971.

Haydon, Colin. "'I love my king and country but a Roman Catholic I hate': AntiCatholicism, Xenophobia and National Identity in Eighteenth-Century England." In Protestantism and National Identity: Britain and Ireland, c. 1650-c. 1850, edited by Tony Claydon and Ian McBride, 33-52. New York: Cambridge University Press, 1998.

Horn, James and Philip Morgan. "Settlers and Slaves: European and African Migrations to Early Modern British America." In The Creation of the British Atlantic World, edited by Elizabeth Mancke and Carole Shammas, 19-44. Baltimore: The Johns Hopkins University Press, 2005.

Marshall, P. J. Introduction to The Oxford History of the British Empire, vol. II "The Eighteenth Century," edited by P. J. Marshall. New York: Oxford University Press, 2008.

Murdoch, Alexander. "Lord Bute, James Stuart Mackenzie, and the Government of Scotland." In Lord Bute: Essays in Re-interpretation, edited by Karl W. Schweizer, 117-146. Leicester: Leicester University Press, 1988.

Olwell, Robert. "Seeds of Empire: Florida, Kew, and the British Imperial Meridian in the 1760s." In The Creation of the British Atlantic World, edited by Elizabeth Mancke and Carole Shammas, 263-282. Baltimore: The Johns Hopkins University Press, 2005.

Pestana, Carla Gardina. "Religion." In The British Atlantic World, 1500-1800, edited by David Armitage and Michael Braddick, 69-88. New York: Palgrave Macmillan, 2002.

Pottle, Frederick A. ed. Boswell's London Journal, 1762-1763. London: Heinemann, 1950. 
Price, Jacob M. "The Imperial Economy." In The Oxford History of the British Empire, vol. II, edited by P. J. Marshall, 169-183. New York: Oxford University Press, 1998.

Rodger, N. A. M. "Sea-Power and Empire, 1688-1793." In The Oxford History of the British Empire, vol. II, edited by P. J. Marshall, 169-183. New York: Oxford University Press, 1998.

Shammas, Carole. Introduction to The Creation of the British Atlantic World, edited by Elizabeth Mancke and Carole Shammas. Baltimore: The Johns Hopkins University Press, 2005.

Wood, Peter H. "From Atlantic History to a Continental Approach." In Atlantic History: A Critical Appraisal, edited by Jack P. Greene and Philip D. Morgan, 279290. New York: Oxford University Press, 2009.

Zahedieh, Nuala. “Economy.” In The British Atlantic World, 1500-1800, edited by David Armitage and Michael Braddick, 51-68. New York: Palgrave Macmillan, 2002.

\section{JOURNAL ARTICLES}

Brewer, John. "The Misfortunes of Lord Bute: A Case-Study in Eighteenth-Century Political Argument and Public Opinion." The Historical Journal 16:1 (1973).

Brown, Iain Gordon. "Water, Windows, and Women: The Significance of Venice for Scots in the Age of the Grand Tour." Eighteenth Century Life 30:3 (2006).

Coclanis, Peter A. “Atlantic World or Atlantic/World?" The William and Mary Quarterly 63 (2006): 725-742.

.Drang Nach Osten: Bernard Bailyn, the World-Island, and the Idea of Atlantic History." Journal of World History 13 (2002): 169-182.

Cohen, Michèle. "The Grand Tour. Language, National Identity, and Masculinity." Changing English 8:2 (2001).

De Ritter, Richard. “'This Changeableness in Character': Exploring Masculinity and Nationhood on James Boswell's Grand Tour." Scottish Literary Review 2:1 (2010).

Games, Alison. "Atlantic History: Definitions, Challenges, and Opportunities." The American Historical Review 111 (2006): 741-757.

. "Introduction, Definitions, and Historiography: What is Atlantic 
History?" Magazine of History 18 (2004): 3-7.

Haynes, Clare. "“A Trial for the Patience of Reason"? Grand Tourists and AntiCatholicism after 1745." Journal for Eighteenth-Century Studies 33:2 (2010).

Kumar, Krishan. "Empire and English Nationalism." Nations and Nationalism 12 (2006): $1-13$.

Lincoln, Margarette. "Shipwreck Narratives of the Eighteenth and Early Nineteenth Century: Indicators of Culture and Identity." The British Journal for Eighteenth-Century Studies 20 (1997): 155-172.

Mapp, Paul W. "Atlantic History from Imperial, Continental, and Pacific Perspectives." The William and Mary Quarterly 63 (2006): 713-724.

Marshall, P. J. "Transatlantic Protestantism and American Independence." The Journal of Imperial and Commonwealth History 36 (2008).

Rounce, Adam. "'Stuarts without End': Wilkes, Churchill, and Anti-Scottishness." Eighteenth-Century Life 29:3 (2005).

Stanwood, Owen. "The Protestant Moment: Antipopery, the Revolution of 1688-1689, and the Making of an Anglo-American Empire." Journal of British Studies 46 (2007): 481-508.

Sweet, Rosemary. "British Perceptions of Florence in the Long Eighteenth Century." The Historical Journal 50:4 (2007).

Sweet, Rosemary. "The Changing View of Rome in the Long Eighteenth Century." Journal for Eighteenth-Century Studies 33:2 (2010).

Wellings, Ben. "Empire-nation: National and Imperial Discourses in England." Nations and Nationalism 8 (2002): 95-109. 


\section{CURRICULUM VITAE}

NAME:

ADDRESS:

DOB:

EDUCATION

\& TRAINING:
Michael Anthony Skaggs

Department of History

Gottschalk Hall

University of Louisville

Louisville, KY 40292

Louisville, Kentucky - March 30, 1987
B.A., History

Indiana University, Bloomington

2005-2009

AWARDS:

Kelley Scholarship
Kelley School of Business

Indiana University, Bloomington

2005-2006

Ryant Memorial Award

Department of History

University of Louisville

2009-2010

Jurdem Graduate Scholarship

Department of History

University of Louisville

2009-2010

Thomas Hamilton Graduate Scholarship

Department of History

University of Louisville

2009-2010

Graduate Assistantship

Department of History

University of Louisville

2009-2010 
Graduate Teaching Assistantship

Department of History

University of Louisville

2010-2011

Departmental Scholarship, Doctoral Program

Department of History

University of Notre Dame

2011-2016 